\title{
OVERGANGER \\ EN STUDIE AV DAS KAPITAL
}

\section{Jørgen Sandemose}

Dette innlegget tar sikte på å klarlegge problemer som vedrører overganger mellom bestemmelser og kategorier innenfor Marx' verk Das Kapital. Det er kanskje fremfor alt karakteristisk for det at det mest mulig unngår å gi generelle definisjoner av objektet og heller legger vekt på enkeltanalyser.

Denne skjevhet har til dels bakgrunn $i$ at de vurderinger som eksplisitt og implisitt taes opp til kritikk, synes å tendere henimot å anlegge et noe for abstrakt syn på overgangsproblemet. Forhåndsanalyser av de mulige steder for overganger i Marx' verk kan her være et tjenlig antidotum.

I pakt med innleggets grunnleggende konklusjon om at det avgjørende skille (»overgang «) innen Das Kapital går mellom verdiplan og prisplan, går mye av plassen med til å vise at det først og fremst hersker parallellitet mellom verkets to første bind. Men et løpende tema som har stor betydning for hele analysen, er hvilke steder - om noen - som i Das Kapital kan tilregnes de overganger Marx først og fremst opererte med i sitt planutkast fra 1857-1858. Vi søker også å vise hvordan disse overganger kan vurderes som momenter i den avgjørende overgang innen Das Kapital, noe som forøvrig tyder på at Marx’ forkastelse av den opprinnelige plan hadde å gjøre med et reelt fremskritt i analysenivå.

Innlegget er utarbeidet med støtte i en forelesningsrekke om forholdet mellom de tre bind i Das Kapital ved Universitetet i Oslo høsten 1976. 


\section{Innledning til overgangsproblemet}

Hans-Jørgen Schanz leverer i nr. 11 av Kurasje en »Skitse til en bestemmelse af overgangen fra II. til III. Kapitalbind« som har vært et inspirerende utgangspunkt for det følgende. Mot Schanz' riktige konklusjon om at problematikken i Marx' reproduksjonsskjemaer gir en implisitt forklaringsbakgrunn for merverdiens overgang til profitt, kan det nemlig innvendes at den er for ubestemt. Schanz innskrenker seg i denne forbindelse til ganske allment å påpeke at i og med reproduksjonsskjemaene »kan vi hurtigt konstatere, at den materielle forms indflydelse på de $\emptyset$ konomiske formbestemmelser tillige fremtvinger reproduktive valoriseringsvanskeligheder «, som så umuliggjør merverdiformen som merproduktets form: altså følger overgangen til profittformen.

Vi er enige i Schanz' kritikk av Marx for å tendere mot å argumentere i sirkel ved overgangen til profitt, i og med at han gjør seg argumentativt avhengig av bevissthetsformen til kapitalisten - dvs. til den økonomiske karaktermaske han nettopp skulle forklare mulighetsbetingelsene for. - Vi er videre enige i at Marx sier lite eller ingenting om »hvilke motsigelser profittformen og kostprisen er uttrykk for«. Videre vil nok Marx på samme måte bli å kritisere for mangelfull konstruksjon av gjennomsnittsprofitt og produksjonspris. ${ }^{1}$

Når vi likevel vil legge vekt på å vise hvordan Schanz' analyse, for å bruke hans egne ord, »kan præciseres og udvikles yderligere « ved et nærmere studium av argumentasjonen i reproduksjonsskjemaene, så henger det sammen med at vi mener at en videreutvikling kan peke på spesielt viktige momenter i Marx' anvendte metode.

Det kan her være tjenlig å begynne med det mest generelle og derfor vanskeligste, nemlig om hvorvidt det berettigede krav om en »immanent « overgang fra bd. II til bd. III uten videre skulle kunne utvides til å gjelde »overgangen « fra bd. I til bd. II (rettere sagt fra produksjonsprosess til sirkulasjonsprosess) og dermed vise seg å være uttrykk for et prinsipp som holder seg identisk like fra den abstrakte fremstillingen av produksjonen fram til fremstillingen av den formidlede produksjonsprosess (i bd. III). Dette siste er etter vårt skjønn et tvilsomt standpunkt, men godtaes tilsynelatende uten videre av Schanz, såvel i »Skitse « som annetsteds. ${ }^{2}$

Schanz hevder at det »må således være klart, at for en immanent fremstilling må overgangen fra 1. til 2. bind anses for at være mangelfuld, for at udgøre en

1. Det er åpenbart at Marx har vært selvbevisst på dette sistnevnte punkt. I kapitel 10 av bd. III sier han nemlig: »Det egentlig vanskelige spørsmål er her dette: hvordan denne utjevning av profittene til den allmenne profittrate foregår, da den åpenbart er et resultat og ikke kan være et utgangspunkt.« Das Kapital, bd. III (MEW bd. 25), s. 183. En lesning spesielt av kapitel 9, ibid., lar en ikke være i tvil om at Marx stort sett behandler utjevningen som et utgangspunkt.

2. H-J. Schanz: Noter til Kapitalens 2. bind, Århus. Jfr. s. 23-28: »Overgangen fra Kapitalens produktionsproces til dens cirkulationsproces.« 
blind plet i fremstillingen $\aleph^{3}$, da man allerede fra begynnelsen av bd. II befinner seg innen sirkulasjonen, dvs. i »det allerede overgangne«, etter at bd. I, uten »noen ansatser til overgangsbestemmelser fra produktionssfæren til cirkulationssfæren $\aleph^{4}$, slutter »med en gennemgang (...) af den kapitalistiske produktionsforms historiskgenetiske betingelser (Die sogennante ursprüngliche Akkumulation)«.

Men faktum er at bd. I slutter med kapitlet om Wakefields Kolonisationstheorie, som ikke kan reduseres til et aspekt ved den »opprinnelige akkumulasjon«. At bindet således avsluttes på et vis som rent tilsynelatende er mindre ideelt for den som venter seg at Marx har levert et typisk stykke »progressiv-regressiv« metode, har foranlediget de underligste innfall. ${ }^{5}$ Årsaken til den plass kritikken av Wakefield inntar, kan man imidlertid finne i Marx' argumentasjon for den opprinnelige plan for Kapital-fremstillingen (1857-1858), til tross for alle forskjeller i forhold til den endelige utgaven av Das Kapital. I et planutkast viser Marx til hvordan kapitalen utvikler seg selv til en sosial totalitet parallelt med at den subsumerer andre sosiale ytringer under seg: 6

»Som totalitet har dette organiske system selv sine forutsetninger, og dets utvikling til totalitet består nettopp i å underordne seg alle samfunnets elementer, eller ut av seg selv å fremskaffe de organer som ennå mangler. Slik blir det historisk til totalitet. Utviklingen (das Werden) til denne totalitet danner et moment i dets prosess, i dets utvikling (Entwicklung). - På den andre siden: når de moderne produksjonsforhold, det vil si kapitalen i dens totalitet, er utviklet innenfor et samfunn, samtidig som dette samfunn bemektiger seg et nytt landområde, slik som f.eks. i koloniene, så finner de (og da særlig deres representant, kapitalisten) at kapitalen har opphørt med å være kapital uten lønnsarbeid, og at en av forutsetningene for lønnsarbeidet ikke bare er grunneiendom overhodet, men moderne grunneiendom; grunneiendom som i egenskap av kapitalisert rente er kostbar, og som sådan utelukker at jorda kan bli umiddelbart utnyttet av individene. Følgelig Wakefields koloniteori, som i Australia ble satt ut i livet av den engelske regjering.«

Denne prosessen oppfatter Marx som en »overgang « fra kapitalens side til grunneiendommen, og den finner sted bl.a. ved at jordprisen tar form av kapitalisert grunnrente og følgelig vil vise en stigende tendens $\mathrm{i}$ og med at bankrenten og grunnrenteraten ${ }^{7}$ tendensielt faller som en funksjon av at profittraten faller. Selve kapitalakkumulasjonen medfører altså ikke bare en ekspropriasjon av produsentene fra grunneiendommen. Den sørger også for en jevnt stigende jordpris og sikrer dermed at proletarene varig hindres i å vende tilbake til jorden. Også dette faktum er

3. Op.cit., s. 24.

4. Dette og det følgende sitat fra op.cit., s. 23-24.

5. Det kan her nevnes at Maximillien Rubel i forbindelse med sin Pléiade-utgave av Marx' Oeuvres lanserte den mulighet at Marx skulle ha føyd til det 25. Kapitel med tanke på den preussiske og russiske sensur: ettersom sensorer av makelighetesgrunner nøyer seg med å slå opp foran og bak i bøkene, ville de nå bare vanskelig kunne finne 24. kapitels politisk farlige ord om »ekspropriatørenes ekspropriasjon«. Den som har lest Marx' kritikk av Wakefield, kan umulig forestille seg at den skulle gi forfatteren større håp.

6. Grundrisse der Kritik der politischen Ökonomie (heretter Grundrisse), Berlin 1953, s. 189.

7. Jfr. bl.a. Das Kapital, bd. III, s. 252 og forøvrig Otto Morf: Geschichte und Dialektik in der politischen Ökonomie, nyutg. Frankfurt am Main 1968, s. 167. 
det av sentral betydning for Marx å få med; men fremstillingen av kapitalakkumulasjonen i kapitlene 21-25 abstraherer fra sirkulasjonen og er følgelig for abstrakt til å kunne begrunne den stigende jordpris in concreto (profitt- og grunnrenterate mangler). Marx nøyer seg derfor med å vise til hvordan kapitalen i koloniene, hvor den ikke behersker samfunnet og følgelig ikke kan regulere jordprisen ad økonomisk vei, streber etter å innføre en høy jordpris abrupt og politisk. Retningsgivende er i alle fall at kapitalens produksjon ikke kan oppfattes som en totalitet før også utestegningen av de allerede eksproprierte produsenter fra jordeiendommen er påvist. ${ }^{8}$ Marx synes tidlig å ha vært klar over Wakefield-teoriens muligheter som ledd i en fremstilling av akkumulasjonen sett fra produksjonens synspunkt. Han bemerker, etter å ha sitert fra Wakefields jordpris-program: »Dette her siterte sted fra Wakefields 'Art of Colonisation' hører med til det som ovenfor er anført om arbeiderens nødvendige atskillelse fra eiendomsbetingelsene «.?

Komposisjonen av bd. I er i dette stykket, vil vi foreløpig si, å oppfatte som et tegn på at Marx har vært seg særdeles bevisst at produksjonsprosessen er å fremstille som en krets, hvor kapitalen tilsist fungerer som en selvreproduserende totalitet, idet »Das Kapital als Grundrente schaffend geht also zurück in die Produktion der Lohnarbeit als seines allgemeinen schöpferischen Grundes « ${ }^{10}$, for å bruke hans ord fra 1858-planutkastet.

\section{Målet og dets størrelse}

Dette standpunkt trenger i høy grad presisering. I denne forbindelse bør det imidlertid først diskuteres om ikke Schanz' argumentasjon for nødvendigheten av en »overgang « av den nevnte type mellom bd. I og bd. II også på egne premisser er for svak. I »Skitse« nøyer han seg etter hva vi kan se med å påstå at en slik overgang ville være nødvendig for å vise at sirkulasjonssfæren med nødvendighet er »subsumert under « kapitalen som et »moment «i denne. ${ }^{11}$ For det første kan det være tvilsomt om det overhodet er riktig å tale om at sirkulasjonen er moment under kapitalens produksjonsprosess slik denne abstrakt blir fremstilt i første bind; det kunne være rimeligere allerede i utgangspunktet å tale om at den er moment under kapitalens formidlede (konkrete) produksjonsprosess som fremstilles i bd. III.

\footnotetext{
8. Den nevnte abstrakthet i analysen av kapitalakkumulasjonen gjør det på den andre siden mulig for Marx å benytte Wakefieldkritikken også til å beskrive omslaget fra »den opprinnelige appropriasjonslov «, et emne han så sent som i 1863 ennå ikke visste hvor burde plaseres innen rammene av bd. I. Jfr. Theorien über den Mehrwert, bk. 1 (MEW bd. 26.1), s. 389.

9. Grundrisse, s. 459.

10. Ibid., s. 189.

11. Jfr. »Skitse«, del II.
} 
For det annet kan det f.eks. - og også gjerne forutsatt at Schanz' versjon av saken var korrekt - like godt tenkes at subsumpsjonsforholdet er av den art at det også fremstillingsmessig først kan utvikles under eller sogar etter den mer abstrakte analyse av kapitalsirkulasjonen som finner sted i bd. II. Rent bortsett fra at det i én henseende er av større betydning at Schanz (på tross av metodologiske ansatser i del I) ikke synes engang å åpne for diskusjon av slike muligheter, skal det nevnes at de vil være retningsgivende for våre egne konklusjoner. Og her bringes vi godt i gang nettopp av det avsnitt av Grundrisse som Schanz primært påberoper seg i sakens anledning - et avsnitt som av Marx ganske riktig er titulert »Overgang fra kapitalens produksjonsprosess til dens sirkulasjonsprosess $«{ }^{12}$

En ting er at når Marx bruker en slik titel i 1858, lar den seg ikke umiddelbart overføre til forholdet mellom de to prosesser slik de hver for seg skildres i Das Kapital. Dette skyldes først og fremst at sirkulasjonsprosessen til dels defineres annerledes. Det annet planutkast ${ }^{13}$ fra 1858 nevner ikke engang ordet, mens man i første utkast ${ }^{14}$ hører om en »Zirkulation der Kapitalien « som er skutt inn under et hovedpunkt og som dekker noen av de emner som senere fikk plass i reproduksjonsskjemaene (og tildels i kap. 49 av bd. III av Das Kapital). Det synes å være en bekreftelse på at begrepet ennå er ubestemt for Marx selv, at han i planutkastet fra 1859 - satt sammen av referanser til avsnittene i den ferdige Grundrisse-teksten - uttaler om sidene 306-310 at de hører hjemme i avdeling II, Kapitalenes konkurranse «, og med dette tydelig vil rykke dem ut av enheten med »Kapitalens sirkulasjonsprosess $\ll .{ }^{15}$ Dette er ensbetydende med at den angjeldende tekst vil være atskillig nærmere beslektet med problematikken omkring profitten og dens oppkomst, dvs. med overgangsbestemmelser til det senere bd. III av Das Kapital, enn med en »overgang « fra bd. I til bd. II. Et slikt synspunkt styrkes av Grundrisse-tekstens bemerkelsesverdige likhet med emnene i de senere reproduksjonsskjemaer, en likhet Schanz selv en passent nevner. ${ }^{16}$ Når Marx her innfører termen Entwertung, som (som Schanz riktig sier) kan sies å representere en overgangsbestemmelse fra produksjon til sirkulasjon all den tid den representerer en potensiell negasjon av den Verwertung som finner sted i den kapitalistiske produksjonsprosess, så skjer det jo først og fremst ved at det vises at »den samlede konsumpsjons kvantum « (Schanz) utgjør en skranke for kapitalen. Moment nr. 2 $\mathrm{er}^{17}$ at kapitalen ved sin $\varnothing \mathrm{kning}$ av det produserte kvantum støter på en skranke i og med den manglende »existensen af ækvivalenter for den ny(mer)producerede værdi, da cirkulationen på dette trin i analysen endnu optræder som en fast størrelse«.

12. Grundrisse, s. 305-325.

13. Ibid., s. $186 \mathrm{f}$.

14. Ibid., s. 175.

15. Ibid., s. 975. Marx innfører her en oppstykking av teksten som burde komme i tillegg til den deling Schanz opererer med, nemlig på den ene side s. 305-318, på den andre s. 318-325.

16. Op.cit., Århus, s. 26.

17. Jfr. bl.a. Grundrisse, s. 310 og Schanz, op.cit., ibid. 
Hva angår dette moment nr. 2, skal vi senere søke å vise at det står særdeles sentralt i Marx' reproduksjonsanalyse, og at det de facto er avgjørende knyttet til problemene som reiser seg i forbindelse med profittformens fremvekst. Inntil videre er det første moment tilstrekkelig til å overbevise om at Grundrisse-teksten vedrører forhold som viser seg aktuelle for avslutningen av bd. II, og at denne avslutning (reproduksjonsskjemaene) ex post framviser momenter som kan oppfattes

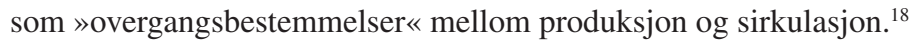

For det første blir det i Das Kapital bd. II - »Kapitalens sirkulasjonsprosess « ikke tale om konsumet som skranke før ved reproduksjonsskjemaene. Det er først ved disse at Marx går over fra den »formelle fremstillingsmanér ${ }^{19}$, hvor det bare forutsettes at den produserte bruksverdi kan konsumeres, til å unders $\varnothing$ ke kapitalens konfrontasjon med et tilsynelatende gitt individuelt og produktivt konsum. Selve Schanz' »Skitse « skulle være den beste henvisning her.

For det annet er det etter vårt skjønn av grunnleggende betydning å innreflektere den fulle mening $\mathrm{i}$ at Marx betegner denne kapitalens skranke med at »Der Gebrauchswert an sich hat nicht die Masslosigkeit des Werts als solchen. Nur bis zu einem gewissen Grade können gewisse Gegenstände konsumiert und sind sie Gegenstände des Bedürfnisses. ${ }^{20}$ Saken er at bruksverdiens Grad, satt opp mot verdiens Masslosigkeit, produserer et nytt Mass, et mål for kapitalverdien, som nettopp er profitten, slik denne (som Schanz har påvist) fremgår av reproduksjonsanalysen. Som bytteverdi overhodet måler verdien seg i en bruksverdi og fremstår dermed som et selvstendiggjort formål i samme grad som bruksverdien selvstendiggjøres som mål (Mass). Som bytteverdi i kapitalform kommer det imidlertid nye bestemmelser til den bruksverdi som tjener som mål; disse nye bestemmelser analyseres i reproduksjonsskjemaene, hvor bruksverdiens status som bruksverdi for første gang analyseres som noe som er avhengig av en sosialt begrenset konsummulighet. »Som bruksverdi er den målt gjennom behovet for den $\ll^{21}$, og

»das Gemessensein durch den Gebrauchswert ist hier fest bestimmt als das Gemessensein durch das Gesamtbedürfnis der Austauschenden für dies Produkt - d.h. durch das Quantum der Gesamtkonsumtion. Diese erscheint hier als Mass für es als Gebrauchswert, und daher auch als Tauschwert «22.

18. Vi benekter altså på ingen måte at Schanz virkelig har truffet på de immanente overgansbestemmelser. Vi vil bare søke å vise at immanensen i dette tilfelle ikke kan vise seg før i den neste overgang, den som vil ligge mellom bd. II og bd. III. Dessuten: at den så å si er en avgjørende kraft når det gjelder om overhodet å få denne overgang igang.

19. Das Kapital, bd. II, s. 393.

20. Grundrisse, s. 308-309. Uthevet her. (»Brugsværdien i sig har ikke den mål-lфshed som værdien som sådan. Kun til et vist punkt kan visse genstande konsumeres, og er de genstande for behovet.« Grundrids, Modtryk/Kurasje s. 290. red.).

21. Ibid., s. 309.

22. Ibid., s. 310. (»Dette at være målt ved brugsværdien (er) her klart bestemt som dette at være målt ved det samlede behov hos de byttende for dette produkt - d.v.s. ved den samlede konsumtions kvantum. Dette fremtræder her som mål for det som brugsværdi og derfor også som byttevardi.« Grundrids, Modtryk/Kurasje s. 291. red.). 
Marx fortsetter ved å kontrastere dette med den form for skranke som finnes i den enkle sirkulasjon, dvs. hos bytteverdien overhodet. Skranken ligger der bare i at varen nå engang eksisterer med en særskilt naturlig beskaffenhet som må »oversettes« til bytteverdiens allmenne form. Annerledes nå: ${ }^{23}$

»Men nå er det postert (gesetzt) at målet for dens tilstedeværelse er gitt i dens naturlige beskaffenhet selv. For å bli oversatt til den allmenne form, må (darf) bruksverdien være tilstede bare i en bestemt kvantitet; en kvantitet hvis mål ikke ligger $i$ det arbeid som er nedlagt $i$ den, men som tvert om fremgår av dens natur som bruksverdi og da som bruksverdi for andre."

Totalt-sosialt sett, dvs. på det reproduksjonsskjematiske nivå vi nå befinner oss, er bruksverdien bare bruksverdi innen de kvantitative grenser som tilsvarer behovet for den. Dette innebærer en tilsvarende modifikasjon av den »bruksverdi« om hvilken det er riktig å si at verdien nå måler seg $i$. Noe som igjen er ensbetydende med $^{24}$ at begrepet om den sosialt nødvendige (verdiproduserende) arbeidstid blir konkretisert: bruksverdier som produseres ut over behovet, har ingen verdi, dvs. representerer bortkastet arbeidstid og er overhodet ikke bruksverdier.

Hva angår den produktive kapital, så består den i utgangspunktet av tilstedevaerende bruksverdier i form av arbeidsmidler, råmaterialer og hjelpestoffer. (Arbeidskraftens bruksverdi, nemlig det levende arbeid, er negerende aktivitet og ikke noe rolig tilstedeværende.) Nå skal - for å foregripe utviklingen et øyeblikk - profittraten ${ }^{25}$ bestå i at merverdien måles på hele den forskotterte kapital, ikke lenger bare på den variable. Og når det $\mathrm{i}$ denne forbindelse oppstår en mystifikasjon om at bruksverdiene, produksjonsutstyret, i seg selv er verdiskapende, så er det selvsagt riktig å tale om dette som en forestillingsform som er kvalitativt mer forherdet enn den som kjennetegner den alminnelige varefetisjisme i den enkle sirkulasjon. - Noe som kan være viktig å understreke, er imidlertid at når det nyproduserte overskudd på denne måten tilsynelatende blir målt i forhold til de »foreliggende « bruksverdier, så er dette et skinn som, vil vi hevde, er karakterisert ved at disse »foreliggende « bruksverdier på forhånd, qua foreliggende, faktisk er blitt vurdert som målbare i kraft av »deres naturlige beskaffenhet selv«.

På denne måten vil kapitalen, i og med det nivå den har »nådd « i reproduksjonsanalysen i bd. II, selv produsere den nye bevissthetsform som tilsvarer profitten. Det er først på denne måten at vi - formelt sett - får et bd. III av Das Kapital, et bind som (slik Marx nok også tenderer i retning av å hevde) omhandler det vi kunne kalle »kapitalen som mål«. I Grundrisse omtaler Marx f.eks. kapitalkonsentrasjonen, som han ennå ser på som noe som skal fremstilles som en følge av »Die Konkur-

23. Ibid.

24. Dette aspektet ved verdibestemmelsen er bl.a. tatt opp av Roman Rosdolsky i Zur Entstehungsgeschichte des Marxschen 'Kapital', s. 116 ff. (Frankfurt am Main 1968).

25. Vi gir denne raten forklaringsprioritet framfor »profitten«, i overensstemmelse med Marx: »Den måte hvorved merverdien, formidlet av overgange gjennom profittraten, forvandles til profittform er bare videreutviklingen av den rokering (Verkehrung) av subjekt og objekt som finner sted allerede i produksjonsprosessen.« (Das Kapital, bd. III, s. 55.). 
renz der Kapitalien ${ }^{26}$, som en »quantitativer Unterschied des Kapitals als zugleich qualitativ, als Mass seiner Grösse und Wirkung $\aleph^{27}$, og dette må - vil vi tro - bli å oppfatte som en fremstilling som finner sitt naturlige utgangspunkt $\mathrm{i} » D$ as an sich selbst gemessne Kapital. Profit. ${ }^{28}$

At kapitalen på denne måten bringes til å reflektere seg i seg selv, innebærer nettopp at profitten er i emning, fordi en slik introrefleksjon peker henimot at det må være til stede et - hittil skjult - subjekt, som holder utviklingen sammen. - Betrakter vi kapitalen som et »i-seg-reflektert produksjonsforhold«, sier Marx i Grundrisse, så betrakter vi nettopp kapitalisten«. Og »kapitalen er vesentlig kapitalist«.

At kapitalens i denne forstand målbare forhold til seg selv faktisk er et refleksjonsforhold, fremgår av en dobbeltgrunn:

For det første er målet, forutsatt den aristotelisk-hegelske tradisjon Marx opererer innenfor, å betrakte som en kvantitet som har møtt skranker som har forvandlet den til en kvalitet. Her er verdien denne kvantitet, som som sådan er Masslos (og altså ikke-kvalitet: rettere sagt kan de enkelte kvaliteter, bruksverdiene, oppfattes som forsvinnende til fordel for kvantiteten (verdien) i den enkle sirkulasjon, forsåvidt som de problemløst kan oversettes til den allmenne form) inntil den treffer på (reflekterer seg i forhold til) konsumskrankene. Imidlertid er dette ikke ensbetydende med noen overgang til kvalitet overhodet; målet er bare å oppfatte som en modifisert kvantitet, og kan som sådan igjen overtrumfe kvaliteten som sådan. (Altså refleksjon tilbake til seg selv.) Det som skjer, er at ${ }^{29}$

»jenes abstrakte Masslose hebt sich zur qualitativen Bestimmtheit auf; das neue Massverhältnis, in welches das zuerst vorhandene übergeht, ist ein Massloses in Rücksicht auf dieses, an ihm selbst aber ebenso eine für sich seiende Qualität; «

Denne teksten skulle understreke at det her dreier seg om de formale årsaker til at vi har med et refleksjonsforhold å gjøre. Men det understreker i det minste riktigheten $i$ at et mål, på prinsipielt samme måte som det målløse, alltid er differensiert og spesifikt for innholdet i de mengder som skal defineres (»måles«). Forsåvidt er det spesifikt også for størrelsen, dvs. størrelser av bestemte typer er »egne« for målene, da størrelser bare er abstraksjoner (f.eks. romlige) fra bestemte innhold, og bare eksisterer in Rücksicht på disse.

For det andre, imidlertid, er de reale årsaker iøynefallende. For selve det faktum at vi i reproduksjonsskjemaene står overfor en bruksverdi som i det minste poten-

26. Grundrisse, s. 186.

27. Ibid. I Das Kapital finner vi, betegnende nok, dette tema igjen ved behandlingen av gjennomsnittsprofittraten: denne bestemmes av enkeltkapitalene ikke alene i kraft av høyden på deres individuelle profittrater, men også i kraft av deres totale verdistørrelse, dvs. av den Wucht de måtte besitte til forskjell fra andre enkeltkapitaler av mindre størrelse.

28. Grundrisse, s. 175.

29. Hegel: Wiss. d. Log., bd. I, utg. Moldenhauer og Michel, Frankfurt am Main 1969, s. 442. Uthevet her. (»Hin abstrakte mål-løshed hæver sig op til den kvalitative bestemthed; det nye målforhold, som det allerede tilstedeværende overgår til, er et mål-løst med hensyn til dette, men ved det selv en ligeså for sig værende kvalitet; « red.). 
sielt er å oppfatte som noe som også har et mål som fremgår av dens »naturlige beskaffenhet « - dette faktum (som, som nevnt, peker hen mot profitten som mål) stammer fra at det er den totale, sosiale sammenheng som der unders $\varnothing$ kes. Det er jo først i denne sammenheng at det blir nødvendig å oppfatte det individuelle og produktive konsum som skranker. Den produktverdi som uttrykker den bruksverdi som står til analyse, er hele det sosiale bruttoprodukt. For: ${ }^{30}$

»Den rent formelle fremstillingsmanér er ikke lenger tilstrekkelig når det gjelder betraktningen av den sosiale totalkapital og dens produktverdi. At en del av produktverdien tilbakeforvandles til kapital, at en annen del inngår i kapitalist- og arbeiderklassens individuelle konsum, danner en bevegelse innenfor selve den produktverdien som totalkapitalen har resultert $i$;

På dette nivå i fremstillingen er den kapital som betraktes altså nødt til å stå i forhold til seg selv (både verdi- og stoffmessig); det finnes ikke noe utenfor den som den kan bytte med, for det er nødvendigvis den totale kapital vi betrakter, såsnart vi oppfatter det samlede konsum som en skranke.

Dette siste er, som implisert, den reale grunn til at vi står overfor en introrefleksjon: kapitalen må bevege seg, men kan her bare gjøre det overfor seg selv. Men ennå er det bare en real grunn til et potensielt forhold; for det faktum at vi reelt har for oss en struktur som kan konstruere profittformen, borger selvsagt ikke for at profitten faktisk fremkommer. For at så skal skje, må det også vises at det nye målforhold som bruksverdien selv er satt i, medfører at det blir umulig for kapitalen å reprodusere seg på disse gitte betingelser.

Det er som nevnt på dette punkt vi mener Schanz er for ubestemt. Den bestemte avledning skal vi fors $\emptyset \mathrm{ke}$ å fremstille i et eget avsnitt, da den er komplisert nok.

En ting kan imidlertid nevnes allerede nå: hvis det er slik at det er bruksverdiens nye målforhold som er den formale betingelse for profittraten, så kan den »opprinnelige « profitt, slik den kommer til syne i fremstillingen av kapitalens totalprosess, ikke være den individuelle kapitals profitt som sådan, slik det ennå er i bd. III av Das Kapital. Tvert om sier det seg selv at overgangen må gå til den sosiale gjennomsnittsprofittrate, i og med at det er den totale sosiale kapital som i så tilfelle er formskapende for profitten. ${ }^{31}$ Bare som en slik totalkapital kan kapitalen fremstilles som refleksjon-i-seg og dermed in embryo som profitt. ${ }^{32}$

30. Das Kapital, bd. II, s. 393.

31. Betrakter man avsnittet s. 338-347 i Grundrisse, som bl.a. omhandler »Die allgemeine Rate des Profits«, så kan det se ut som om Marx vil avlede en gjennomsnittsprofittrate nettopp av en struktur som formalt svarer til de senere reproduksjonsskjemaer. (I det minste er utgiverne av denne oppfatning, jfr. ibid., s. 1098.) Men her dreier det seg om begreper som Marx i 1857-1859 ennå ikke hadde utviklet helt og fullt. Det er derfor vanskelig herfra å utlede noe om en mulig plan for utviklingen av Das Kapital.

32. Vi har da også annetsteds søkt å vise at gjennomsnittsprofittraten må tenkes som et resultat mer av den kapitalistiske arbeidsdeling og dens trang til overproduksjon innen enkeltbransjer, enn av konkurransen »i og for seg«. Jfr. »Transformasjonsproblem og verditeori«, i Marx $i$ dag (antologi), Oslo 1973. Videre bl.a. »Den kapitalistiske samfunnsformasjon. Et grunnriss.« Stensil, Oslo 1973. 


\section{Lønnsarbeidet som formalt subjekt}

Vi forlot betraktningen av bd. I med å vise til en formodet kretskarakter i fremstillingen av den umiddelbare produksjonsprosess. Men i den grad denne krets - slik det er rimelig - er å oppfatte som et produkt av at totaliteten er selvproduserende (Selvet har kretsform), er det klart at den er abstrakt. Dette framgår i og for seg allerede av at utestegningen av arbeiderne ikke påvises ved hjelp av grunnrentekategorien, som i dette tilfellet ville være den konkrete kategori. Men mer bestemt er det forårsaket av at det Selv som det er tale om ikke er kapitalistens - slik det fullt ut skulle tilsvare et legeme som Das Kapital -men lønnsarbeiderens. Som Schanz riktig bemerker, er det i bd. I slik at »arbejdslønnen (lønarbejdet) er ... garantien for at arbejdskraften uden extraøkonomisk tvang permanent vil reproducere sig i vareform. I II. Kapitalbind vises derimod, at den rene formreproduktion ikke slår til.« «3 Inntil det sistnevnte skjer, foregår gjenstandens selvreproduksjon ved hjelp av et reservesubjekt, og da et formalt subjekt, ettersom det kjennetegner lønnsarbeiderne at de qua eiendomsløse står i et rent, abstrahert, formforhold til produksjonsmidlene. Først kapitalisten er ett med disse midler og er et reelt og innholdsmessig subjekt.

Forsåvidt kapitalen ved avslutningen av bd. I »in die Produktion der Lohnarbeit als seines allgemeinen schöpferischen Grundes zurückgeht «, så er det altså egentlig lønnsarbeidet som går tilbake i seg selv, via arbeidslønnen. Dette er av sentral betydning for en kritisk vurdering av Marx' påstand om at lønnsformen er avgjørende for fremveksten av profittformen. Som den står, har den ren forsikringskarakter, som også Schanz viser. Marx hevder dels ${ }^{34}$ at en fremstilling av gjennomsnittsprofitten krever en forutgående fremstilling av arbeidslønnen, dels at det eksisterer et realt årsaksforhold mellom lønnens skinnkarakterer og profittens eksistens ${ }^{35} »$ Fordi arbeidskraftens pris ved den ene pol fremstår i den forvandlede form av arbeidslønn, fremstår merverdien ved motpolen i den forvandlede form av profitt.«

En slik tenkemåte er desto mer overraskende sålenge Marx selv påpeker den formelle karakter i fremstillingen i bd. I ${ }^{36}$ Om vi gjør ham den tjeneste å ta de førnevnte utsagn på ordene, vil det imidlertid stille seg annerledes. For i begrepet om arbeidslønnen ligger det at den er inntekt, slik at den kontinuerlig og periodisk tilfaller arbeideren. Denne kontinuitet, og forsåvidt lønnskategorien selv, er reell først på bakgrunn av en fremstilling av systemets selvreproduksjon. Vi skal nå se på hvilket samband denne fremstilling kan ha med profittkategorien, og det er da rimelig å ta utgangspunkt i at reproduksjonsprosessens gjentakelse i seg selv, »die-

\footnotetext{
33. »Skitse «, note nr. 44.

34. Jfr. brev til Engels av $27.61867, M E W$ bd. 31, s. 312 f.

35. Ibid., og Das Kapital, bd. III, s. 46.

36. Jfr. note 30 , ovenfor.
} 
se blosse Wiederholung oder Kontinuität«, tilfører produksjonsprosessen »visse nye karakteristika ${ }^{37}$

Denne enkle reproduksjon betrakter Marx som nevnt som noe som formidles av at arbeideren betales på etterskudd og følgelig stadig er tvunget til å inngå i en ny kontrakt med kapitalisten for å forsørge seg. Ikke desto mindre opprettholdes skinnet av at den variable kapital er noe »opprinnelig forskottert « fra kapitalistens side. Dette skinn kan oppløses av analysen, noe vi nå skal søke å vise. Imidlertid må vi nevne at det er av sentral betydning å notere seg at kapitalisten i første omgang fremstilles som en pengebesitter hvis rikdom ikke stammer fra utbytting av lønnsarbeidere. Vi skal nemlig komme tilbake til dette faktum i forbindelse med vurderingen av reproduksjonsskjemaenes enkle reproduksjon og dennes eventuelle parallellitet med den enkle reproduksjon slik den skildres i bd. I. Videre i forbindelse med en nyvurdering av det behov for nye ekvivalenter ved produksjonsøkning, som vi har sett Marx peke på i Grundrisse. Først Marx: ${ }^{38}$

»Imidlertid, sin betydning (Sinn) av å være en verdi forskottert fra kapitalistens eget fond vil den variable kapital først miste såsnart vi betrakter den kapitalistiske produksjonsprosess i dens stadig fornyende strøm. Men den må jo begynne fra et eller annet sted og tidspunkt. Utifra vårt hittidige standpunkt er det derfor sannsynlig at kapitalisten en eller annen gang ble gjort til pengebesitter gjennom en eller annen opprinnelig akkumulasjon som var uavhengig av fremmed, ubetalt arbeid, slik at han kunne skride inn på markedet som kjøper av arbeidskraft. Imidlertid vil den kapitalistiske produksjonsprosess' blotte kontinuitet, eller den enkle reproduksjon, bevirke ytterligere, særegne forandringer, forandringer som ikke bare angår den variable kapitaldel, men totalkapitalen.«.

Han fortsetter med omtrent følgende tankeeksperiment: Om en slik kapital i utgangspunktet blir sett på som en inntektskilde på f.eks. 10000 pund som avkaster 2000 pund (produsert merverdi) årlig, så vil dens ekvivalent være fortært i individuell konsumpsjon (merverdien investeres nemlig, etter forutsetningen om enkel reproduksjon, ikke i produksjonsmidler eller arbeidskraft) i løpet av en periode på fem år. Og dette er ensbetydende med at den opprinnelige kapital er forsvunnet (fortært). Det er et rent skinn som får kapitalisten til å forestille seg at det er den nyproduserte merverdien og ikke den opprinnelige kapitalverdien han konsumerer. Det spiller i denne forbindelse ingen rolle at han stadig har hos seg en kapital av uforandret størrelse, stofflig sett bestående av produksjonsmidler: for

»her dreier det seg om kapitalens verdi og ikke om dens materielle bestanddeler. Om en person fortærer hele sin eiendom ved å stifte en gjeld som er ekvivalent med eiendommens verdi, så representerer nettopp hele eiendommen den totale sum av hans gjeld. På samme måte: når kapitalisten har fortært ekvivalenten til sin forskotterte kapital, så representerer denne kapitalens verdi bare den totale sum av den merverdi han har tilegnet seg uten vederlag. Ikke et verdiatom av hans gamle kapital eksisterer videre.«

37. Das Kapital, bd. I, s. 594.

38. Das Kapital, bd. I, s. 594. Uth. her. 
Det er dermed vist at selve prosessens forekomst inkluderer en reproduksjon av et antagonistisk (klasse)forhold. Men av Marx sammenfattes dette i en setning hvor terminologien er tvilsom: ${ }^{39}$

»Helt bortsett fra all akkumulasjon vil altså produksjonsprosessens blotte kontinuitet, eller den enkle reproduksjon, etter en kortere eller lengre periode nødvendig forvandle enhver kapital til akkumulert kapital eller kapitalisert merverdi.«

At denne identifikasjon av kapitalisert merverdi med akkumulert kapital er forvirrende, indikeres bl.a. av ordbruken i det for vårt øvrige formål særdeles viktige kapitel 17 i bd. II, »Die Zirkulation des Mehrwerts«, hvor kapitalisering av merverdien oppfattes som det samme som akkumulasjon også av materielle elementer til produksjonsprosessen. ${ }^{40}$ Først og fremst kommer det til syne i kapitel 2 i samme bind, hvor det hevdes at »Akkumulasjonen ... blir imidlertid videre hen, som vist $\mathrm{i}$ første bind, gjennom sin utvikling til en nødvendighet for hver enkelt kapitalist. En jevn vekst $i$ kapitalens st $\phi$ rrelse blir til en betingelse for kapitalens opprettholdelse. Imidlertid behøver vi ikke komme tilbake til det tidligere utviklede. $\aleph^{41}$

Det kan være et skjønnsspørsmål om Marx med dette sikter til det siterte eksempel på ren kontinuitet i den kapitalistiske produksjonsprosessen. Sikkert er iallfall at en med nфdvendighet følgende akkumulasjon ikke er vist, og langt mindre »utviklet «, i bd. I. Dette ville også være direkte urimelig, da fremvisningen av en slik nødvendighet for enkeltkapitalenes vedkommende måtte være foregrepet av en fremvisning av hvordan samme nødvendighet gjelder for den totale sosiale kapital - hvis det skulle gjøres krav på nødvendighet uten utfluktmulighet. En slik sosial kapital forekommer imidlertid så å si pr. definisjon ikke i bd. I, men først i reproduksjonsskjemaene. Ser man så litt nøyere på disse, vil det etter vårt skjønn også vise seg at de inneholder en begrunnelse for akkumulasjonens nødvendighet. Denne begrunnelse faller i stort også sammen med grunnen til profittformens oppkomst. ${ }^{42}$

\section{Opphevelse av den enkle reproduksjon}

Marx' likevektsformel for byttet mellom sektor I (produsent av produksjonsmidler) og II (produsent av konsumpsjonsmidler), hvor

$$
\mathrm{I}(\mathrm{v}+\mathrm{m})=\mathrm{IIk} \text {, }
$$

39. Sitater fra Das Kapital, bd. I, s. 595.

40. Jfr. Das Kapital, bd. II, ss. 321 og 326.

41. Ibid., s. 84. Uth. her.

42. Referatet av Marx' fremstilling i pkt. VI nedenfor er av undertegnede i en annen sammenheng blitt brukt i en undersøkelse av konkurransebegrepets forhold til akkumulasjonsanalysen i Das Kapital. Jfr. tidsskriftet Kontrast, Oslo, nr. $3 / 4$ 1971, s. 54ff. 
eksemplificeres i bd. II med

$$
\text { I } 4000 \mathrm{k}+\underbrace{1000 \mathrm{v}+1000 \mathrm{~m}}
$$

II .................. 2000k + 500v $+500 \mathrm{~m}$.

Slik dette bytteforholdet - som forsåvidt ikke behøver å fremvise noe brudd på den $\varnothing$ konomiske likevekt om det så fortsatte i det uendelige - er satt opp, regnes all kapital for å være flytende, dvs. å slå om i løpet av den betraktede produksjonsperiode. Mens det er viktig å merke seg at skjemaet er realistisk bl.a. i den forstand at forekomsten av de to sektorer er avledet av varekapitalens kretsløp, et kretsløp som av seg selv skiller individuell og produktiv konsumpsjon til to forskjellige grener, er det klart at skjemaet også er abstrakt. Den viktige konkretisering vi her vil konsentrere oss om, er den som foretaes i avsnitt XI av bd. II's kapitel »Enkel reproduksjon «, nemlig »Erstatning av den faste kapital « ${ }^{43}$

Som det egentlig fremgår av titelen, er abstraksjonen om en helt ut flytende kapital nå oppgitt. Dermed er det heller ikke lenger slik at de 2000Ilk årlig fullt ut kan omsettes ${ }^{44}$ in natura mot de naturalbestanddeler av konstant kapital som II trenger og som er materialisert i $2000(\mathrm{v}+\mathrm{m})$. Tvert om vil store deler av IIk (faste kapitaldeler) fungere videre i naturalform. Samtidig vil en del av verdien 2000IIk bestå av en ekvivalent for slitasje på fast kapital, dvs. for den del av den faste kapital som nettopp ikke skal erstattes in natura, men bare i pengeform. Vi benevner denne delen (s.) og setter den til 200, som altså skal hopes opp av kapitalistene II til et fond for senere fornyelse av fast kapital. »Bytteforholdet« skulle dermed bli 1800IIk mot 2000(v+m). Skjematisk:

$$
\text { I ….......... } \underbrace{1000 \mathrm{v}+1000 \mathrm{~m}}
$$

$$
\text { II .............. 1800k + 200v(s.) …..... }
$$

1000 på hver side av regningen kan besørges umiddelbart: Da nemlig arbeiderne som tidligere nevnt generelt betales på etterskudd, har arbeiderne I faktisk $1000 \mathrm{i}$ penger hos seg - fra forrige produksjonsomgang. Disse penger formidler nå en omsetning av konsumvarer IIk til en verdi av $1000^{45}$, og dermed har kapitalistene I fått klargjort naturstoffet arbeidskraft til neste produksjonsomgang. Forholdet blir nå

$$
\begin{aligned}
& \text { I …....... 1000m } \\
& \text { II ......... } \quad 800 \mathrm{k}+200 \mathrm{k}(\mathrm{s} .) \ldots \ldots \ldots . .
\end{aligned}
$$

43. Das Kapital, bd. II, s. 446ff.

44. At det i denne forbindelse bare er IIk som kommer inn i bildet, skyldes selvfølgelig at vi ikke analyserer noe annet enn byttet mellom sektorene. Som all annen konstant kapital i sektor I, blir utslitt fast kapital innen 4000Ik erstattet av sektorens eget produkt.

45. Her viser det seg - likesom på den enkle reproduksjons produksjonsnivå i bd. I - igjen hvordan hele systemet er avhengig av lønnsarbeiderklassens formidling. 
som, om likevekt skal opprettholdes, synes å skulle forutsette et varebytte av $1000 \mathrm{~m}$ mot $800 \mathrm{k}$, noe som løper ut $\mathrm{i}$ at vareeierne I skulle forære vareeierne II et beløp på 200 i pengeform for å få til en smertefri reproduksjon. Dette er selvsagt fiktivt; det som kan byttes ut, er 800 i vareverdi fra hver sektor. Resultatet er

I …...... 200m

II .................... 200k(s.) .........

at altså, for å si det med Marx, »en femtedel av merverdi I er uomsettelig, kan ikke forvandles fra sin naturalform som produksjonsmidler til en naturalform som konsumpsjonsmidler.« - Følgelig er de 200k(s.) heller ikke omsettelige, de kan ikke forvandles fra sin naturalform som konsumpsjonsmiddel til pengeform. En slik forvandling forutsetter at II her fremstår som »blott selger« av en vare, for så å opphope de 200 i pengeform uten å kjøpe noe til gjengjeld. Likevekt er dermed tilsynelatende umulig, eller rettere, problemet er å finne ut hvor de overskytende 200 i pengeform skal komme fra - og det er åpenbart bare løsbart såfremt en ser denne fremstilte årlige reproduksjon i sin sammenheng, kontinuitet ${ }^{46}$

»Når vi betrakter den årlige reproduksjon - og også på det enkle nivå, dvs. idet vi abstraherer fra all akkumulasjon - så begynner vi ikke ab ovo. Det er et år i en lengre rekke, det er ikke den kapitalistiske produksjons fødselsår. De forskjellige kapitalene som er anlagt i de forskjellige produksjonsgrenene $\mathrm{i}$ sektor II er av forskjellig alder ... og i dette året når mengder av faste kapitaler sin livsaften og må fornyes in natura ved hjelp av akkumulerte pengefonds."

Sektor II skulle dermed kunne fremstilles som bestående av to avdelinger:

II(1)med slike kapitaler hvor den faste kapital må fornyes in natura sammen med den flytende, og

II(2)med slike hvis faste kapital fungerer videre, og som in natura bare skal fornye sin flytende, mens ekvivalenten for slitasjen på den faste kapital samles opp i pengefonds (her i Marx' konstruksjon 200k årlig).

Når vi altså ikke begynner $a b$ - ovo, men homerisk in medias res, så ser vi at II(1) bare kan fornye fast kapital in natura ved hjelp av pengefonds som allerede foreligger innen II(1) selv, fonds tidligere samlet opp gjennom varesirkulasjon. Hva angår kjøpet av denne faste kapital, opptrer II(1)som »blott kjøper« av varer fra I. Det finner ikke sted noe vekselsidig bytte av varer i naturalform. II(1) er altså i stand til slik å kjøpe de 200Im - såfremt de representerer fast kapital - uten selv å levere varer. Med disse pengene, 200, ekvivalent for solgt vare, kjøper I de resterende $200 \mathrm{k}$ (s.) som foreligger i vareform hos II(2), hvoretter II(2) har oppfyllt sin rolle som »blott selger « og kan deponere 200 i pengeform i fonds for senere erstatning av $\sin$ faste kapital in natura. Den enkle reproduksjon er smertefritt fullført, hva gjelder både kapitalens verdi- og stoff-fornyelse.

46. Das Kapital, bd. II, s. 450. 
Forutsetningen for en slik smertefrihet er for det første at verditapet som følge av slitasje på den viderefungerende faste kapital (her 200) er identisk med verdien av den faste kapital som har dødd bort, dvs. representert ved de tidligere oppsamlede pengefonds innen II(1). Marx sier: ${ }^{47}$

»En slik likevekt fremstår dermed som en lov for reproduksjon på likeblivende nivå; noe som med andre ord betyr at innen den produksjonsmiddelproduserende sektor I må den proporsjonelle arbeidsdelingen forbli uforandret mellom produsenter av på den ene siden flytende og på den andre siden faste elementer av den konstante kapital som skal leveres til sektor II.«

At en slik likevekt er umulig å opprettholde har ikke sin umiddelbare årsak i for$\varnothing$ kelsesprosessen, men i arbeidsprosessen, dvs. i den bruksverdienes forgjengelighet som ligger utenfor kapitalistklassens kontroll. Det viktigste eksempel, anført av Marx, er:

Ifølge forutsetningen for enkel reproduksjon skal bruksverdimengden og verdisummen av de produksjonsmidler som går fra I til II år for år være den samme, her 2000. Om det i løpet av et år slites ut mer fast kapital innen IIk enn i året forut, må også en større del av de 2000(v+m) bestå av fast kapital, og en tilsvarende mindre del av flytende kapital.

»Samtidig skulle totalproduksjonen i sektor II forbli den samme. Og hvordan skulle dét være mulig, med forminskning av dens kvanta råstoffer, halvfabrikata, hjelpestoffer?« ${ }^{48}$

På forhånd eksisterer det dessuten en disproporsjon mellom slitasjeverdidelen innen II(2) og de pengefonds som II(1) anvender til innkjøp fra I. Resultatet er i alle tilfelle som Marx sier: »Krise - produksjonskrise - trass i reproduksjon på likeblivende nivå. ${ }^{49}$

Dette resultat, som Marx sammesteds legger meget stor vekt på, er etter vårt skjønn å oppfatte som den bestemte variant av Schanz' konklusjon. Det vises her at den enkle reproduksjon både materielt og verdimessig er umulig å opprettholde..$^{50}$ Følgelig forklares det også immanent at akkumulasjonen er noe som med nødvendighet opptrer, idet den er den eneste mulige utvei ${ }^{51}$ for å slippe unna disproporsjo-

47. Ibid., s. 461.

48. Ibid., s. 463.

49. Ibid., s. 463; uthevet her.

50. Grossmann skriver til Mattick, forøvrig med et forståelig spark til datidens Sorel'ske »marxisme«: »Om De engang konsekvent tenker Marx' tanke til ende - om hvordan det i den enkle reproduksjon, hvor alt synes å være i en så harmonisk likevekt, kan oppstå en krise -, først da kommer De til å oppdage mang en teoretisk tanke hos Marx, som »filosofene« ikke har drømt om - og det gjelder også slike som K. Korsch, som innbiller seg at de forstår noe som helst av den marxske økonomi.« Idem: Marx, die klassische Nationalökonomie und das Problem der Dynamik, utg. Frankfurt am Main 1969. Jfr. Anhang. Briefe Henryk Grossmanns an Paul Mattick über die Akkumulation. S. $112 \mathrm{f}$.

51. Rent formalt sett finnes det en annen utvei, nemlig forminskning av produksjonsvolumet, og så en stabilisering av den enkle reproduksjon på et lavere nivå. I virkeligheten er dette ikke nødvendig å ta i betraktning, idet reproduksjonsskjemaene allid forutsetter et gitt minimum av verdistørrelse hos kapitalen tilsvarende det tekniske nivå produksjonen har nått. Den nevnte »utvei« ville dermed heller være identisk med permanent nedleggelse av den kapitalistiske produksjon - så å si både på 
nalitetskrisen i den enkle reproduksjon. Det er dermed blitt etterrettelig å si at det er et sammenfall mellom kapitalopprettholdelse og kapitaløkning. Det formelle resultat fra den enkle reproduksjon i bd. I blir materielt fyllt av resultatet av analysen av samme fenomen i bd. II. ${ }^{52}$ Implisitt er det dermed også vist at akkumulasjonen må bevege seg i ulikevekt bransjene imellom, ettersom den enkle reproduksjon alltid utgjør en del av den utvidede. Sammenholder en dette med det vi ovenfor har anført om forholdet mellom reproduksjonsskjema og gjennomsnittsprofitt (jfr. konklusjonen ved pkt. II), vil en få en mer konkret »modell « for forklaring av denne profittens oppkomst, en oppkomst som jo er knyttet til forholdet mellom flere kapitalistiske bransjer. Vi kommer tilbake til dette under punkt VI.

Foreløpig er det først og fremst viktig å fastslå sammenhengen mellom denne tvang til akkumulasjon og profittformen: krisen i den enkle reproduksjon er nettopp det konkrete uttrykk for at

»reproduktionens erstatningslogik, som udvikles igennem merværdi og værdiformer (men tillige med henblik på den stoflige erstatning og ækvivalensformidlingen) står nødvendigvis i modsætning til reproduktionens verwertungslogik.«

»Profitformen er da«, som Schanz fortsetter ${ }^{53}$, »den form, hvori alene denne modsætning kan bevæge sig.«

Vi tror det finnes grunn til å anta at en slik organisk sammenheng mellom fremstillingen av den faste kapitals reproduksjon og av profitten har vært nærliggende hos Marx selv. Vi skal komme tilbake til dette i punkt VI. Først er det imidlertid

verdi- ogstoffside. - En parallell argumentasjon finner man forøvrig hos Marx i analysen av produksjonstiden (bd. II, kap. 13), hvor en »forkortelse av produksjonens nivå forkastes som en mulig løsning på de mange mulige brudd på det jevnt vekslende forløp av arbeids- resp. sirkulasjonsperioder hos enkeltkapitalene. (Dette er brudd som viser til nødvendigheten av tilleggskapitaler i forhold til den tenkte utgangssituasjon for analysen og som forsåvidt - på abstrakt, dvs. på enkeltkapitalenes, nivå går på de samme forhold som de som kommer i fokus ved overgangen fra enkel reproduksjon til akkumulasjon. Reelt dreier det seg imidlertid om delanalyser hvis utviklingsgang bare kan forståes på bakgrunn av at det hos den totale kapital vises en tilsvarende gang. Denne siste - som på det mest konkrete altså kommer til syne i avsnitt XI av kapitel 20 i bd. II - må da imidlertid selvsagt fremstilles som værende uavhengig av den førstnevnte. Og i realiteten er det da også slik at Marx i reproduksjonsskjemaene finner det rettferdiggjort å regne med et harmonisk forhold mellom arbeidsperioder og sirkulasjonsperioder - nettopp i kraft av å ha analysert dem i annet avsnitt av bd. II.).

52. Den første som fortjenestefullt har pekt på denne parallellitet mellom bindene I og II er såvidt vi kan se Etienne Balibar, i (med Althusser) Lire le Capital: trans., Milano 1968, s. 279-285. (Konklusjonen ser ut til å bli brukt på en annen måte enn det er tilfellet for vårt vedkommende.) - Fra en forsøksvis mer fagøkonomisk vinkel har Rudolf Hilferding (Das Finanzkapital (1911), nyutgave Frankfurt am Main 1968, s. 335-338) og Bruno Fritsch, Die Geld- und Kredittheorie von Karl Marx, Frankfurt am Main 1968, s. 98, pekt på krisen i den enkle reproduksjon i bd. II. Lenger kommer de heller ikke. Hilferding er nemlig hovedsaklig interessert i proporsjonene innen de faste kapitaler og konsentrerer seg ikke synderlig om det i vår sammenheng avgjørende aggregatet $\mathrm{Im}$. Fritsch har på forhånd stengt seg ute fra en vurdering av Im, idet han (jfr. ibid., s. 92, note) tror at det er unødvendig å følge m-delenes vandel i skjemaene når man først følger v-delenes, all den tid den konstante merverdirate innebærer at m-delene alltid står $\mathrm{i}$ et fast forhold til den variable kapital. Dette er riktig, men det innebærer at en ser bort fra bruksverdi- og »etterspørsels«- siden i skjemaene.

53. Sitater fra »Skitse «, del V. 
nødvendig å fremstille et av de viktigste indisier, nemlig hvordan Marx’ løsningsfors $\varnothing \mathrm{k}$ angående problemet (skranken) med det begrensede antall ekvivalenter inntar plassen umiddelbart etter reproduksjonen av den faste kapital i teksten i bd. II. Vi skal konsentrere oss om avsnitt XII i »Enkel reproduksjon«, som behandler »Reproduksjonen av pengematerialet $\ll .{ }^{54}$

\section{Gullgraving}

Hvis det virkelig har vært Marx' mening å vise akkumulasjonens immanente nødvendighet ut fra erstatnigen av den faste kapital, vil det være å vente at han rettferdiggjør påstanden ved å vise at det samtidig foreligger (ny)ekvivalenter nok til å besørge sirkulasjonen av den vare- og kapitalmengde som ved akkumulasjon vil måtte komme i tillegg til den allerede eksisterende. Det er de facto også det han gjør; for som det er bekjent, inneholder avsnitt XII et bevis for at det vil finne sted opphopning av gull (tesaurering) i produksjonssystemet, til tross for enkel reproduksjon. Marx’ resonnement er imidlertid gjennomgående blitt misforstått, spesielt under Rosa Luxemburgs og Henryk Grossmanns ledelse. En kritikk av deres synsmåter er dermed i seg selv nødvendig, ${ }^{55}$ desto mer som Grossmann for sin del foregir å kunne rekonstruere den del av Marx' tekst som er gått tapt, og som Luxemburg for sin del apriori finner uinteressant. Men dessuten vil en slik kritikk være svært nyttig av fremstillingsgrunner, ettersom Marx' tekst kan være av en slik art at den fremstilles best når en viser til dem som ikke har forstått den. Her vil det først og fremst bli Grossmann vi konsentrerer oss om, noe teksten hurtig vill rettferdiggjøre.

\section{A. Grossmann: Gullproduksjonen som falsk utgift}

Det som kommer i betraktning er altså: »reproduksjonen av pengematerialet «, som for enkelthets skyld oppfattes som bare gull. Når det er tale om enkel reproduksjon, er det klart at reproduksjonen kun skal dekke det gull som hvert år forsvinner fra sirkulasjonen på grunn av slitasje. Marx opererer med en gullindustri med en total dimensjon på $20 \mathrm{~K}+5 \mathrm{v}+5 \mathrm{~m}$ (hvor altså de generelle proporsjonene k:v:m i skjemaene er overholdt; jfr. pkt. IV). Imidlertid vil dette ikke bety at sirkulasjonsslitasjen er ekvivalent med 30 verdienheter. Pengematerialet, gullet, fungerer nemlig

54. Das Kapital, bd. II, s. $465 \mathrm{ff}$.

55. Det kan vel sies at Grossmanns variant i dag råder grunnen alene og uimotsagt. Det dreier seg om hans artikkel »Die Goldproduktion im Reproduktionsschema von Marx und Rosa Luxemburg « fra 1932. Den siteres her eftter nyutgaven, idem: Aufsätze zur Krisentheorie, Frankfurt am Main 1971, s. 77-109. Angående Luxemburg: Die Akkumulation des Kapitals, Berlin 1913, kapitel 5: »Die Geldzirkulation«, s. 65-79. 
også til industrielle formål, og det etter forutsetningen både i sektor II (f.eks. hos kapitalistiske tannteknikere og juvelérer) og i sektor I. Selv hører gullproduksjonen »som metallproduksjon overhodet ${ }^{56}$ (som Marx sier) til i sektor I, og den eneste grunn til nettopp denne plasering er, synes det rimelig å si, at gullet ikke bare tjener til sirkulasjons-, men også til produksjonsformål.

Imidlertid: for hele Grossmanns fremstilling er det retningsgivende at han innskrenker gullproduksjonen til å skulle dekke slitasjen på pengematerialet. Til sin støtte trekker han fram noen setninger fra kapitel 17 i bd. II, »Sirkulasjonen av merverdien $\ll{ }^{57}$ Han glemmer at Marx i dette kapitlet - liksom i alle øvrige som behandler kapitalomslaget ${ }^{58}$ - utgår fra enkeltkapitalenes synspunkt, noe som selvsagt i vesentlig grad blir »modifisert « i reproduksjonsskjemaene. ${ }^{59}$ Vi skal ikke her gå nærmere inn på denne forskjellen, men heller fortsette med å hevde at det er fullstendig fallert av Grossmann i denne sammenheng å hevde at ${ }^{60}$

»produksjon av gull som varemateriale for industrielle formål overhodet ikke skiller seg fra en hvilken som helst annen metallproduksjon (...) og dermed overhodet ikke er noe problem«.

Vi skal tvert om senere søke å vise at gullproduksjonen også i denne henseende skiller seg ut, noe som har sammenheng med at den produksjon vi nå betrakter (i reproduksjonsskjemaene, og ikke på enkeltkapital-nivå!) er nært knyttet sammen med sirkulasjonsprosessen.

Allerede på dette punkt vet vi desverre nok til å kunne betvile den vitenskapelige ærlighet som måtte ligge i intensjonen i Grossmanns kritikk av Luxemburg. ${ }^{61}$ Det er nok også i full bevissthet om at hans svake stilling kan avsløres av hvem som helst som vil kaste bare et blikk på kapitel 20, avsnitt XII, at han fortsetter: ${ }^{62}$

»Det er bare den monetære gullproduksjon som er problematisk. Det er bare med hensyn til denne at Rosa Luxemburg har levert sine kritiske innvendinger mot Marx. Altså er det også bare den vi trenger å drøfte.«

Hvem som helst kan kaste et tilsvarende blikk på tonen i artikkelen forøvrig, for å finne ut at en slik god vilje til å gi motparten retten til å styre debatten må ha helt

56. Das Kapital, bd. II, s. 466.

57. Jfr. Grossmann, op.cit. 1932, s. 90, og Das Kapital, bd. II, s. 328.

58. Unntaket er bare avsnitt III i kap. 16: »Den variable kapitals omslag, samfunnsmessig betraktet «.

59. Jfr. note 51 , ovenfor.

60. Op.cit. 1932 , ibid.

61. Det mangler på norsk noen forsvarlig oversikt over Luxemburgs arbeid som Grossmanns kritikk her kan perspektiveres mot. I tillegg til det som her måtte komme fram mht. hennes syn på »pengesirkulasjonen«, skal vi bare generelt nevne at Die Akkumulation des Kapitals jevnt over er preget av sammenblanding (de facto, i det minste) av Marx' skjema for akkumulasjonen med hans skjema for enkel reproduksjon. Denne forveksling reproduseres av T. Krogh i en kritisk »kommentar« til Rosa Luxemburgs teorj. I denne »kommentar« får vi opplyst at akkumulasjonen hos Marx er utstyrt med både konstant og(hva forholdet mellom bransjene angår) lik organisk kapitalsammensetning. Jfr. Rosa Luxemburg: Skrifter i utvalg, Oslo 1973, bd. 2, s. 11. Bindredaktør: Jon Elster.

62. Op.cit. 1932, ibid. 
spesielle årsaker. (Vi skal komme tilbake til at Grossmanns påstand om Luxemburgs kritikk forøvrig er misvisende i seg selv.)

Vi kan la dette være som det vil; det vesentlige er at Grossmann - noe vi også skal begrunne i det følgende - de facto setter likhetstegn mellom gullproduksjon og pengeproduksjon og dermed kan komme i skade for å legge seg nær den fetisjisme som i realiteten hevder at gull fra naturens hånd er penger. At et slik forvirring faktisk er tilstede, fremgår av hans passasje om at ${ }^{63}$

»av gull kan man ikke lage noen produksjonsmidler (maskiner, bygninger osv.), eller, som Marx sier: 'pengene er i seg selv ikke noe element i den virkelige reproduksjon' «.

Her bør man (vi kan se bort fra konteksten forøvrig) legge merke til hvordan Grossmanns tilsynelatende akseptable abstraksjon fra industriell gullutnyttelse slår over i en påstand om at gull reelt ikke kan fungere som produksjonsmiddel. Og dette skjer utifra (blant annet) en identifikasjon av »pengene« og »gull«. - En ting er forøvrig at Grossmanns påstand kan tilbakevises selv av en gullsmed, som jo bruker gull som råstoff (Grossmann glemmer for anledningen at produksjonsmidler innbefatter råstoffer og hjelpestoffer, noe ikke minst gullindustriens folk kan bekrefte!) og dermed deltar i det som Marx ville kalle den »virkelige« reproduksjon. (Her: i konsumsektoren). En annen ting er at Grossmanns påstand er en nødvendig følge av at han vil utvide Marx' sats om at ${ }^{64}$

»Hele den summen av arbeidskraft og sosiale produksjonsmidler som blir engasjert i den årlige produksjon av gull og sølv som sirkulasjonsinstrumenter, utgjør en tungtveiende post innen den kapitalistiske produksjonsmåtes,... faux frais (d.e. »overflødige kostnader«; J.S.)《

til å gjelde edelmetallproduksjon overhodet, idet han ganske enkelt ser bort fra at Marx, selvsagt, bare lar det gjelde for edelmetall $i$ den grad det tjener som »sirkulasjonsinstrument $\ll$.

I pakt med dette unders $\varnothing$ ker Grossmann hele spørsmålet om reproduksjonen av gullmaterialet primært ut fra en slik vurdering av »vareproduksjonens faux frais. «

I likhet med Marx benevner han verdienhetene fra gullproduksjonen med g, der dette er nødvendig for oversiktens skyld. (Den korrekte benevnelse på gullindustrien blir da Ig, ettersom den hører hjemme i produksjonsmiddelsektoren.) Han tar så utgangspunkt i talleksemplene i Marx' skjema (jfr. innledningen til pkt. IV ovenfor), og viser til hvordan det her opereres med en samlet produktiv kapital, dvs. unntatt den nyskapte merverdien, som samfunnsmessig sett skal konsumeres uproduktivt, på 7500 verdienheter. (Nemlig i sektor I: 4000k + 1000v. Og i sektor II: $2000 \mathrm{k}+500 \mathrm{v}$.) I forbindelse med at den produktive kapital i gullindustrien jo er $20 \mathrm{k}+5 \mathrm{v}=25$, hevder han deretter at ${ }^{65}$

63. Ibid., s. 91. Marx-sitatet går til Das Kapital, bd. II, s. 486.

64. Das Kapital, bd. II, s. 347.

65. Op.cit. 1932, s. 97. 
"gullproduksjonen betyr en innskrenkning av vareproduksjonens omfang. Hvis gullproduksjonen beløper seg til 25g, så må den produktive kapital ... innskrenkes med nettopp denne sum, dvs. fra 7500 til 7475. Det vil si: En kapital på 25 må for uproduktive sirkulasjonsformål overføres fra den produktive industri til gullindustrien.«

Dermed investeres - ifølge Grossmann - 20k $+5 \mathrm{v}(=25 \mathrm{~g})$ i angjeldende industri, hvoretter man får ut en merverdi på 5 etter endt produksjon. Det er på denne måten en ender opp med den produktverdien 20k $+5 \mathrm{v}+5 \mathrm{~m}$ som Marx opererer med.

Det Grossmann hevder, er altså at de $25 \mathrm{~g}$ anlegges som en følge av at de to sektorene yter »pengeforskotteringer til gullprodusenten«, noe de er »tvunget « til for at få igang en produksjon av $25 \mathrm{~g}$, som de altså har mistet via sirkulasjonsslitasje. Videre er det av betydning at hver sektor trenger penger i forhold til sin produktive kapitals størrelse. Ettersom produksjonen i sektor I er dobbelt så stor som i sektor II, gir I altså ut $16,67 \mathrm{~g}$ til gullprodusenten, mens II gir ut $8,33 .{ }^{66}$ Som Grossmann bemerker, innebærer dette en »forbigående « senkning av deres pengekvantum med ytterligere 25g. Den er forbigående, fordi gullprodusenten »sofort « bruker de mottatte 25 enheter til å kjøpe produksjonsmidler og konsummidler (til arbeidskraften) fra sektorene I og II, slik at de kan investere $20 \mathrm{k}+5 \mathrm{v}$ i produktiv virksomhet for å fremskaffe en merverdi. Ved denne bruken flyter imidlertid de $25 \mathrm{~g}$ tilbake til sektorene I og II i en annen proporsjon enn den de fløt ut i; ettersom den organiske sammensetning i skjemaene nemlig er 4, flyter det fire ganger så mange enheter tilbake til produksjonsmiddelsektoren som til konsumvaresektoren: $20 \mathrm{k}$ og $5 \mathrm{v}$. Dette medfører at sektor I får tilbake 3,33 verdienheter mer enn den har utgitt, og II 3,33 færre. Ved første øyekast kan dette synes å bekrefte essensen i Luxemburgs Marx-kritikk, idet denne bl.a. hevder at sirkulasjonsslitasjen hos Marx bare kan erstattes utelukkende på bekostning av sektor II. - Dette er, hevder Grossmann videre, imidlertid bare en éngangsfremtredelse. For samtidig på kortest mulige måte å sammenfatte hans konklusjon, kan man nemlig betenke at gullprodusenten, såsnart han har fått sin geskjeft igang, vil øke den forskotterte kapital med en merverdi, slik at den verdi som skal reproduseres er produktverdien $20 \mathrm{k}+5 \mathrm{v}+5 \mathrm{~m}$. Er man først kommet så langt, altså til begynnelsen av gullkapitalistens (gullgraverens) 2. produksjonsperiode, så vil avdelingene I og II for fremtiden alltid $»$ ta like stor del, dvs. proporsjonalt til sine kapitalstørrelser, i de overføringene (Abgaben) som skjer med erstatning av pengeslitasjen for $\varnothing y e . «^{67}$ I forbindelse med at hele gullindustriens kapital - forøvrig i likhet med all annen kapital i de to sektorene - slites ut i løpet av produksjonsperioden, vil forholdet nemlig bli at kapitalistene i sektor I selger produksjonsmidler til en verdi av 20 til gullgraveren, mens sektor II selger konsumvarer til en verdi av 10 til gullgraveren (for $5 \mathrm{~m}$ ) og hans ansatte (for $5 \mathrm{v}$ ).

Dermed er vi fremme ved Grossmanns oppreklamerte løsning på »Marx’ tilsynelatende paradoksale påstand om at det vil finne sted en gullakkumulasjon,

66. Jfr. Ibid., s. 104, hvorfra også det følgende referat er tatt.

67. Ibid., s. 107. 
selv om vi antar at det bare finner sted enkel reproduksjon såvel i vare- som i gullproduksjonen, dvs. at gullproduksjonens omfang forblir uforandret fra år til år. $\ll^{68}$

For det som nå - mener Grossmann - vil skje kontinuerlig »fra år til år«, er at sektor I jevnlig vil få tilbake 20g i penger, altså 3,33g ut over sitt behov på 16,67g; samt at sektor II jevnlig får tilbake $1,67 \mathrm{~g}$ (nemlig $10 \mathrm{~g}-8,33 \mathrm{~g}$ ) ut over sitt. Tilsammen legges det dermed hvert år opp 5g som ikke er nødvendig for sirkulasjonen, og disse $5 \mathrm{~g}$ kan opphopes (tesaureres) slik (som »reserveskatt «) fordi det har oppstått en merverdiproduksjon av samme størrelse i gullindustrien. ${ }^{69}$

\section{B. Marx: Gullproduksjonens to retninger}

Vi vil holde det ovenstående for å være et rimelig referat av Grossmanns oppfatning, og skal nå vende oss til Marx' fremstilling.

Innledningsvis skal det imidlertid nevnes at det som sagt er misvisende å hevde at Luxemburg begrenset sine kritiske innvendinger til å gjelde den monetære gullreproduksjonen. Denne påstanden tjener heller til å dekke over at Grossmann og Luxemburg er skjønt forent i kunstig å ville isolere pengevareproduksjonen fra produksjonen av edelmetall til produktive formål. Vi skal komme tilbake til en detaljert kritikk her. Det viktige er å slå fast hovedårsaken til at en slik isolasjon er forkastelig.

Saken er at når gullet har nådd fram til å bli allmenn ekvivalent, altså pengevare, så skyldes dette at gullet opprinnelig er en vare innen varenes krets, altså en vare, eller også: et produkt, på linje med alle andre. Pengevaren kommer ikke utenfra som en rasjonalistisk oppfinnelse, men er allerede tilstede. Dens formforvandling til pengevare har denne opprinnelige tilstedeværelse som sin forutsetning, og denne opprinnelighet reproduserer seg kontinuerlig innen den eksisterende vareproduksjon vi betrakter, på den måten at en del av såvel det eksisterende som av det gullet som er unner nyproduksjon går til »industrielle« formål. Det er virkelig en ufornuftig påstand fra Luxemburgs side at produksjonen av denne sistnevnte del av den totale samfunnsmessige gullmengde »har like lite med pengeproduksjonen å gjøre som produksjonen av skosverte. « ${ }^{70}$ Tvert om er Marx' analyseform i »Reproduksjonen av pengematerialet « en bevisst videreføring av den generelle vareanalysen, med dens vekt på prosesserende enhet av forskjellighet av bruksverdi og verdiform.

Det er derfor også barnaktig av Grossmannn å forestille seg at sektor II og sektor I (minus gullgraverbransjen!) har noe behov for å sette igang en gullproduksjon

68. Ibid., s. 102.

69. Saken er, sier Grossmann annetsteds, at »merverdien i gullproduksjonen, tvert imot alle den enkle reproduksjons forutsetninger, samfunnsmessig sett ikke er konsumérbar og derfor nødvendigvis må tesaureres.«Ibid., s. 102.

70. Op.cit., 1913, s. 74. 
utenfor seg selv. Gullproduksjonen er allerede til stede i deres midte. Det er bemerkelsesverdig å se hvordan han på den ene siden fremhever, ja rent ut vil bygge sin analyse på, pengeproduksjonen er faux frais i vareproduksjonen (som bl.a. vel nettopp derfor er å oppfatte som et anarkisk system), mens han på den neste forutsetter at $\varnothing$ konomien er oversiktelig nok til at man på bestilling ex nihilo kan drive en industrireising for å produsere overflødigheten.

Denne selvmotsigelse tar seg uttrykk i at det hos Grossmann ikke kan finnes noe prinsipp for regulering av størrelsen på den investering som opprinnelig skal foretaes i gullgraving. Selv hevder han riktignok at dette prinsipp er etterspørselen etter sirkulasjonsmidler (her $25 \mathrm{~g}$ ), som så til slutt fører til at produktverdien gull settes sammen som

$20 \mathrm{k}+5 \mathrm{v}+5 \mathrm{~m}=30(\mathrm{~g})$.

Men hvis en skal forutsette at de øvrige kapitalister har et så godt overblikk over den totaløkonomiske situasjon, så er det fornærmelig å hevde at de ikke skulle regne med at g-industrien vil få ut en merverdi av produksjonen. De kan følgelig innskrenke sin samlede investering fra 25 til 20, noe som etter én produksjonsperiode vil vise seg å være forenlig med en produktverdi på

$16,67 \mathrm{k}+4,167 \mathrm{v}+4,167 \mathrm{~m}=25(\mathrm{~g})$,

og som faller sammen med etterspørselen på en slik måte at 1) proporsjonene for enkel reproduksjon opprettholdes, og 2) tesaurering ikke finner sted, på Grossmanns egen premiss.

Grossmanns løsning er følgelig kontingent, og det er det beste som kan sies om den. Og en slik kontingens er etter vår oppfatning det nødvendige resultat av ikke å se på gullindustrien som en leverand $\phi r$ både til produksjon og sirkulasjon; dette nemlig $i$ det minste forsåvidt dette dobbeltforhold følger $n \phi d$ vendig av at gullindustrien er noe allerede foreliggende innen produksjonssystemet.

Ifølge det siste må en $n \phi d v e n d i g v i s$ begynne analysen av pengematerialets reproduksjon med å dele den foreliggende produktverdi g (her: en verdi som uttrykker seg i 30 pengeenheter) i to porsjoner. Marx antyder en deling som tilsier at $2 / 5$ av den går til produksjonsmidler og 3/5 til å erstatte sirkulasjonsslitasje. Dette forslaget vil vi følge gjennemført opp i vår fremstilling, også når det gjelder vårt fors $\varnothing \mathrm{k}$ på rekonstruere den tekst som mangler i Marx’ manuskript. Vi vil videre gjøre den legitime forutsetning at denne proporsjon gjelder ikke bare for produktverdien $\mathrm{g}$ in toto, men også for hvert enkelt aggregat $(\mathrm{k}, \mathrm{v}, \mathrm{m})$ innen denne verdien. (Som det vil fremgå, er en deling av den omtalte type et gjennomgangstema hos Marx, i den grad at en må finne det høyst merkverdig at Grossmannn overhodet våget å påstå noe annet).

Ser vi på Ig's produktverdi, nemlig,

$20 \mathrm{k}+5 \mathrm{v}+5 \mathrm{~m}$, er det klart at $5 v+5 m$ (i tråd med innholdet i det generelle byttet av $\mathrm{I}(\mathrm{v}+\mathrm{m})$ mot IIk) skal byttes mot elementer innen IIk, slik at arbeidere og kapitalister innen Ig får noe konsumere. Ved alminnelige forutsetninger skal $(5 \mathrm{v}+5 \mathrm{~m}) \mathrm{g}$ bestå av 
produksjonsmidler. I dette tilfellet vet vi imidlertid at bare $(2 \mathrm{v}+2 \mathrm{~m}) \mathrm{g}$ har denne destinasjon, idet $(3 \mathrm{v}+3 \mathrm{~m}) \mathrm{g}$ skal tjene som nytt sirkulasjonsmiddel.

Utifra dette skal vi forsøke å referere Marx’ syn på bytteprosessen

$\operatorname{Ig} 20 \mathrm{k}+\underbrace{5 \mathrm{v}+5 \mathrm{~m}}$

II ............. 10k

hvor 10IIk er konsumpsjonsmidler, forsåvidt likegyldig hvilke. Vi skal først vurdere omsetningen av $5 \mathrm{v}(\mathrm{g})$ mot 5IIk.

»Hva angår de 5v«, begynner Marx, »så starter enhver gullprodusent med å kjøpe arbeidskraft; ikke med gull han selv har produsert, men med en andel av de penger som er tilstede i landet. For disse $5 \mathrm{v}$ skaffer arbeiderne seg konsumpsjonsmidler fra II, som på sin side med de samme pengene kjøper produksjonsmidler fra I. «11

Dette er særlig viktig fordi det minner om den sentrale formidlingsrolle som tilligger den variable kapital både i dens funksjon som pengekapital og i dens etterfølgende funksjon som arbeidslønn. Denne formidlingsrolle er dessuten nært knyttet til det vi ovenfor har omtalt som lønnsarbeidernes egen reproduksjon av kapitalforholdet. Lønnsarbeiderens selvstendighet kommer her til uttrykk i at det er ham selv, og ikke på noen måte kapitalisten (her: innen Ig) som besørger første del av omsetningen med sektor II. Omsetningens mål - sett med øynene til kapitalisten Ig - er at kapitalistene II skal kjøpe de av hans produksjonsmidler som er inkarnert i v+m. Men denne operasjonen vanskeliggjøres av at halvparten av disse produksjonsmidler verdimessig sett (og bare verdimessig - for lønnsarbeideren defineres ved at han ikke besitter produksjonsmidler) hviler hos arbeiderne. Sagt med andre ord: deres verdimessige uttrykk, dvs. pengene $5 \mathrm{v}$, må overføres til kapitalistene før omsetningen I $(\mathrm{v}+\mathrm{m})$ mot IIk kan fullbyrdes. Denne overføring ligger i at arbeiderne I kjøper konsumvarer fra kapitalistene II, som først dermed skaffer seg penger nok til å overta hele $\mathrm{I}(\mathrm{v}+\mathrm{m})$-produktet av produksjonsmidler.

Dette er forhold som Marx også av andre grunner finner det nødvendig å minne spesielt om i forbindelse med analysen av gullproduksjonen ${ }^{72}$, og de tjener til å kaste lys over det utrivelige i at Grossmann, som vi ovenfor har referert ${ }^{73}$, taler om at gullprodusenten blir forskottert med 25 pengeenheter (fra sektorene I og II) som han så bruker til å investere i produksjonsmidler og konsumvarer til arbeidskraften. En slik struktur kan overhodet ikke forekomme i den kapitalistiske produksjon. Tvert om: kapitalisten investerer i arbeidskraft, og arbeidskraften kjøper konsumvarer. ${ }^{74}$

71. Das Kapital, bd. II, s. 467.

72. Jfr. Ibid., s. 468.

73. Se forøvrig op.cit. 1932, s. 104.

74. I dette stykket overgåes Grossmanns fors $ø$ k langt av Luxemburgs fra 1913. Luxemburg tok - som Marx - utgangspunkt i den variable kapitals særegne funksjon nettopp når hun skulle beskrive sirkulasjonsmidlenes struktur i økonomien: »Salget av arbeidskraft og arbeidernes frie kjøp av livsmidler er kapitalproduksjonens avgjørende moment.«(Op.cit., s. 66). 
Vi kan nå gå tilbake til den betraktede omsetning.

Vi har - med Marx - sagt at II kjøper produksjonsmidler for »de samme pengene «, dvs. med de opprinnelige v(g). Vi kan merke disse pengene: $5 \mathrm{v}(\mathrm{g})$ ', for å understreke at de stammer fra allerede sirkulerende gull, slik vi har sett Marx hevde. Vanskeligheten er nå at II her ikke kjøper for alle de $5 \mathrm{v}(\mathrm{g})^{\prime}$, men bare for $2 \mathrm{v}(\mathrm{g})^{\prime}$. De resterende $3 \mathrm{v}(\mathrm{g})$ ' er det ikke bruk for i naturalelementene i den konstante kapital i sektor II. De vil derfor heller ikke flyte tilbake til lg, og denne vil dermed, kan det synes, ha vanskelig for å skaffe tilveie tilstrekkelig av naturstoffet arbeidskraft til bruk i den kommende produksjonsomgang, ettersom de $2 \mathrm{v}(\mathrm{g})$ ' bare dekker $2 / 5$ av verdien av dette stoffet.

Hadde det dreiet seg om en hvilken som helst annen bransje, ville da også reproduksjonen ha blitt umulig. Ikke slik her. For i én produksjonsperiode har Ig hatt arbeidere beskjeftiget med å produktverdi, $(20 \mathrm{k}+5 \mathrm{v}+5 \mathrm{~m}) \mathrm{g}$. Vi noterer oss at det er lønnssomt å benevne enhetene innen dette produktet med (g)", da de er produsert senere enn det gullsom utgjorde den variable kapital som Ig tok i bruk da vi startet analysen av hans bevegelse. Det sentrale er nå at av dette (nyskapte) produkt som er i hans eget eie, kan Ig simpelthen trekke ut $3 \mathrm{v}(\mathrm{g})$ ) og betale dem direkte til sine arbeidere i tillegg til de $2 \mathrm{v}(\mathrm{g})$ ' - uten å gå veien om en omsetning med sektor II. For i gullproduksjonen faller bruksverdiside så å si sammen med verdiside, ettersom det konkrete arbeid og det konkrete produkt vi der finner, er representant for det abstrakte arbeid, respektivt for verdien, i det $\varnothing$ konomiske systemet som helhet. Det gullst $\varnothing \mathrm{v}$ som tilsvarer de $5 \mathrm{v}$, er ikke blitt et atom forringet av at $3 \mathrm{v}(\mathrm{g})$ ' ikke flyter tilbake til $\mathrm{lg}$; de 3 stammer jo fra tidligere sirkulasjon og produksjon. »Hans arbeidere«, sier Marx, « har levert ham 5 i gull, hvorav han har solgt 2 og besitter 3 i gull; disse 3 kan han ganske enkelt mynte ut eller forvandle til sedler, slik at hans samlede variable kapital igjen befinner seg i hans hånd i pengeform, uten videre formidling av II. «75 (Marx bemerker hvordan engelske diplomater i USA i en publikasjon fra 1879 med misundelse beretter hjem om hvordan »gullgraverne bringer en betraktelig mengde naturgull direkte til mynten i San Francisco«.)

Reproduksjonen av gullmaterialet $\mathrm{v}$ er dermed klargjort.

Men i tillegg til denne (enkle) reproduksjon finnes det nå overskytende $3 \mathrm{v}(\mathrm{g})$ ' innen IIk, eller rettere sagt hos de kapitalister som helt eller delvis er bærere av dette aggregatet. Men her har de ikke noe å gjøre, bl.a. ${ }^{76}$ fordi den konstante kapital II allerede er reprodusert. Innen aggregatet IIv har de heller ingenting å gjøre, idet kapitalistene II må forutsettes å være i besittelse av tilstrekkelig pengekapital v som en følge av salg av konsumpsjonsmidler (produkt av sektor II selv) til arbeiderne i

75. Das Kapital, bd. II, s. 467.

76. For vår sammenheng (ffr. pkt. IV) er det interessant at Marx nevner den rent kontingente mulighet for at de kan forbli i IIk - eller bedre sagt: utøve en funksjon i reproduksjonen av den konstante (her: den faste delen) kapital - forutsatt at IIk(1) er mindre enn IIk(2). 
den egne sektoren. Det eneste aggregat hvor de kan finne hvile er IIm, fordi de der ikke forstyrrer den sosiale reproduksjons smertefrie forløp. Følgelig 77

»må disse penger i sin helhet overføres fra IIk til IIm, uansett om nå denne sistnevnte eksisterer i form av nødvendige livsmidler eller i form av luksusmidler - og omvendt må en tilsvarende vareverdi overføres fra IIm til IIk. Resultat: en del av merverdien blir tesaurert (als Geldschatz aufgespeichert). «

Etter denne betraktning av den variable kapital og dens materielle tilsvarighet, kan vi gå over til den andre komponenten i Ig's bytte med IIk, nemlig merverdien.

Her er forholdene straks mindre kompliserte, fordi den komponent som skal utskiftes umiddelbart og allerede er i kapitalistenes eie, både bruksverdi- og verdimessig. Merproduktet er pr. definisjon et nyprodusert produkt og ikke noe som tidligere på den ene eller den andre måten hørte sirkulasjonen til. Kapitalistene kan kaste sin vare, gullet, altså $\operatorname{Im}(\mathrm{g})$ )", direkte inn i sirkulasjonen, ettersom »gull kan kjøpe alle varer«. Han får konsumpsjonsmidler til en verdi av 5 tilbake fra II, som bruker $2 \mathrm{~m}(\mathrm{~g})$ " til materialer i sin konstante kapital (sammen med $2 \mathrm{v}(\mathrm{g})$ '). Det $\emptyset$ vrige blir, og må bli, tesaurert i IIm. ${ }^{78}$ Marx fortsetter: ${ }^{79}$

»Det viser seg - også bortsett fra Ik, som vi senere skal betrakte - hvordan det selv ved enkel reproduksjon, også når (som her) akkumulasjon i ordets egentlige betydning, dvs. reproduksjon på utvidet nivå, er utelukket, er nødvendig innbefattet at gullmagasinering eller tesaurering finner sted.«

Det endelige resultat er i så måte en opphopning av gull (i sektor II) i en mengde som uttrykkes i 6 pengeenheter. Av disse vil 3(v) være produsert i et tidligere år, og 3(m) i siste år. Resultatet inkluderer at kapitalistene II tilsammen konsumerer bruksverdier til en verdi av bare 494 pr. år.

\section{Gullgraverens konstante kapital}

Til vurdering gjenstår nå det tredje aggregat, som vi i tråd med det før nevnte kan kalle Ik(g)", som som nevnt ikke får sin reproduksjon behandlet hos Marx.

For alminnelige vareproduserende kapitaler vil gjelde at de erstatter sin konstante kapital in natura ved gjensidige varebytter innen det totale sosiale aggregat Ik (hos Marx: 4000Ik). Men dette er en regel som for Ig's vedkommende bare halvveis er riktig. I tråd med hva vi ovenfor har nevnt om at hvert g-aggregat analytisk må deles i porsjoner, må det nemlig forutsettes at kapitalene innen de $\varnothing$ vrige 3980Ik bare har behov for $8 \mathrm{k}(\mathrm{g})$ " til bruk som materialer. ${ }^{80}$

77. Das Kapital, bd. II, s. 468.

78. »...wird ...wieder Element der Schatzbildung als in Geld verharrender Teil von Im.« Ibid., s. 468f.

79. Ibid., s. 469.

80. Det er rimelig å tenke seg at dette behov er relativt mindre her, enn det er i konsummiddelindustriene. Ettersom poenget i begge tilfelle bare er å se på konsekvensene av gullvarens dobbeltfunksjon i skjemaene, trenger vi ikke ta hensyn til dette. 
Om prinsippet om gjensidig bytte mellom kapitalene skulle legges til grunn, slik Marx for enkelhets skyld gjør i annen sammenheng, ${ }^{81}$ ville Ig altså ikke ha mulighet til å fornye $3 / 5$ av sin konstante kapital. Men da dens produkt jo består av gull som kan kastes direkte inn i sirkulasjonen og altså kjøpe alle varer, står vi overfor nye forutsetninger. I realiteten vil Ig på denne måten kunne erstatte hele sin konstante kapital, og det er også den eneste vei til å fullføre en slik erstatning. ${ }^{82}$

Hele $I(k+v+m) g$ er dermed reprodusert. Men om vi også videre skulle legge Marx' opprinnelige skjema-proporsjoner til grunn, ville det innebære reproduksjonskrise, idet 12 enheter av de $\varnothing$ vrige 3980Ik ikke ville kunne bli reprodusert in natura, men bare verdi- og pengemessig. Det er etter forutsetningen utelukket at Ik skulle kunne finne erstatning for dette ved å kjøpe fra aggregatet $\mathrm{I}(\mathrm{v}+\mathrm{m})$, ettersom det her bare finnes produksjonsmidler som er spesielt tilpasset konsumvareproduksjon. ${ }^{83}$

Nå er det i og for seg selvsagt ikke noe i veien for å godta en umiddelbar reproduksjonskrise. Et slikt resultat er rimelig på ethvert nivå i reproduksjonsanalysen og vil bare vise det umulige i på sikt å opprettholde den enkle reproduksjon. Forutsetningen er imidlertid at det ikke kommer på tvers av en like rimelig eller rimeligere mulighet for opprettholdelse av proporsjonalitet. Vi skal søke å argumentere for at en slik mulighet foreligger som en naturlig konsekvens av introduksjonen av gullproduksjonen i skjemaet, og at den forøvrig også har været Marx' intensjon.

Det eneste alternativ til en overføring av de $12 \mathrm{k}(\mathrm{g})$ )" mellom aggregatene Ik og $\mathrm{I}(\mathrm{v}+\mathrm{m})$ er nå ifølge det ovenstående at de forblir innen Ik, men ikke som varer, tvert om som sirkulasjonsmidler, som - med utgangspunkt i de innkjøp Ig gjør fra andre kapitalister i den hensikt å fornye sin konstante kapital - sirkulerer fra den ene

81. Se bd. II, kap. 20, avsnitt VI: »Den konstante kapital i avdeling I.«

82. Marx nevner denne erstatningsmåten for gullkapitalens vedkommende i »Sirkulasjonen av merverdien «, bd. II, s. 328.

83. Om en forestilte seg en slik erstatningstype virkeliggjort, ville det, også tatt i betraktning den manko innenfor IIk som vi skal se finnes, lede til en disproporsjon i byttet mellom hovedsektorene som følge av at de $12 \mathrm{k}(\mathrm{g}) \ll$ ikke ville kunne bidra til erstatning in natura. Denne disproporsjon kan bare forbigående (nemlig for é_produksjonsperiode) leges ved å ta den periodiske erstatningen av den faste delen av IIk i betraktning, og da bare for det tilfellet at underavdeling II(1) var nettopp 12 enheter mindre enn II(2). Dette ville medføre at sektorbyttet på utviklingstrinn (4) ville fremstå som

I ... 200m

II ........ $212 \mathrm{k}(\mathrm{s}$.$) ,$

noe som, i dette forenklede eksempel hvor Marx regner med bare to års omslagstid for den faste kapital, betyr at det foreligger $188 \mathrm{k}$ (s.) som tidligere er opphopet og som nå kan gå til kjøp av $188 \mathrm{~m}$ i produksjonsmidler fra I. Dermed ville $12 \mathrm{~m}$ i pengeform bli tilbake hos I og reproduksjonen være smertefritt fullført. Men selvsagt ville også et slikt ønsketilfelle medføre et omslag i neste produksjonsperiode, hvor de 212 ville høre hjemme hos II(1), og hvor Im ikke vil være omfattende nok til å dekke det oppståtte behov i sektor II. 
produsent av produksjonsmidler (til bruk ved produksjon av produksjonsmidler) til den andre.

Dette er plausibelt nok, da det imøtekommer forutsetningen om at utslitt sirkulasjonsgull i en gitt utstrekning årlig skal erstattes av nyprodusert gull som flyter inn i sirkulasjonen. I motsetning til de tidligere behandlede $3 \mathrm{v}(\mathrm{g})$ ' og $3 \mathrm{~m}(\mathrm{~g})$ " blir de $12 \mathrm{k}(\mathrm{g})$ " nemlig ikke tesaurert og kan heller ikke bli det. Om det skal forutsettes full reproduksjon in natura innen Ik, så må de tvert om, med utgangspunkt i Ig, som kaster dem ut i sirkulasjonen, vandre fra hånd til hånd og ved ethvert tilfelle bære bruksverdier fra den ene vareprodusent til den andre. De må så å si utelukkende bare tjene den umiddelbare reproduksjon av de foreliggende kapitaler innen I.

Dermed er også problemet berørt: på hvilken måte er forekomsten av de $12 \mathrm{k}(\mathrm{g})$ " innen Ik overhodet forenlig med aggregatets fulle reproduksjon in natura? Saken er jo at innføringen av dem innebærer at aggregatet mister en del av sin anvendte arbeidstid (til 12 verdi-og pengeenheter) i produksjonen til sirkulasjonen.

Løsningen kan her bare bestå i en modifikasjon av verdistørrelsen på den kapital som i sektor I produserer produksjonsmidler, dvs. av størrelsen på all derværende kapital minus den som er anlagt i gull, ettersom problemets utgangsbetingelse ligger $\mathrm{i}$ en diskrepens mellom verdiproduksjon og produksjonsmiddelproduksjon.

I realiteten er spørsmålet blitt formulert på denne måten av både Luxemburg og Grossmann, om enn på en sviktende manér, og ikke med utgangspunkt i unders $\emptyset$ kelsen av reproduksjonen av Ik. Det gjør seg her gjeldende en strid dem imellom om hvorvidt det dreier seg om en $\varnothing$ kning eller minskning av den totale verdimengde i skjemaet. Luxemburg holder på økning, Grossmann derimot på en reduksjon, som rimelig er utifra hans gjennomførte faux frais-oppfatning. ${ }^{84}$

Formelt sett er det Luxemburg som har rett, til tross for alle reservasjoner som må gjøres mot hennes fremstilling. Vi velger å ta utgangspunkt i hennes kritiske vurdering av formidlingen I $10(\mathrm{v}+\mathrm{m}) \mathrm{g}=$ II 10k, hvor Marx som nevnt finner at det som en konsekvens vil finne sted en overføring av $6 \mathrm{~g}$ fra IIk til IIm og derved også en overføring av tilsvarende vareverdi til IIk. Det er dette som får Luxemburg til å anta at Marx’ Geldaufspeicherung skjer på bekostning av kapitalistene II: ${ }^{85}$

»Ikke bare kan de, til tross for »abstinens«, ikke foreta noen utvidelse av sin produksjon; de er ikke engang istand til å igangsette sin produksjon i det tidligere omfang. For selv om den tilsvarende »vareverdi overføres fra IIm til IIk, så er det ikke bare verdien, men denne verdiens tinglig-konkrete skikkelse det

84. Jfr. Grossmann, op. cit. 1932, s. 99f. Som tidligere fremhevet, er Grossmanns og Luxemburgs premisser forøvrig sammenfallende, idet de feilaktig regner med at en $\varnothing$ kning eller minskning vil innbefatte hele verdimengden Ig, og ikke bare den del av den som går til sirkulasjonsmiddelproduksjon, noe vi på vår side vil gjøre gjeldende. (Se nedenfor).

85. Die Akkumulation des Kapitals, s. 74. 
kommer an på. Og da en del av produktet fra I består av penger, som ikke kan brukes som produksjonsmiddel, så vil II, til tross for abstinens, ikke i fullt omfang kunne fornye sin konstante kapital in natura. Og dermed ville skjemaets forutsetning om enkel reproduksjon være forlatt $\mathrm{i}$ to henseende: opphopning av merverdien og manko i den konstante kapital.«

Det er, i forbifarten bemerket, karakteristisk for Grossmann kritikk-metode at han nevner Luxemburgs kritikk på dette punkt, for deretter å hoppe lett forbi den ved å skjule dens kontekst fullstendig (bl.a. ved systematisk ufullstendige sitater fra Die Akkumulation des Kapitals). Men saken er at Luxemburg her peker på et vesentlig punkt, som Marx forøvrig etter vårt skjønn må ha villet gjøre til bindeledd mellom fremstillingen av reproduksjonen av $\mathrm{I}(\mathrm{v}+\mathrm{m}) \mathrm{g}$ og $\mathrm{Ikg}$.

I forbindelse med tesaureringen innen IIm er det ingen tvil om at man står overfor en mulig reproduksjonskrise. Overføringen av en vareverdi 6 til IIk har nemlig ført til at sistnevnte aggregat før det $\varnothing v$ vrige bytte med sektor I består av 1996 enheter, mens I består av 1990. Altså kan det ikke annet enn å oppstå en rest på 6 i IIk, som da selvsagt blir returnert til IIm og konsumert av kapitalistene II. Samtidig vil det ha vist seg at totalproduktet $\mathrm{I}(\mathrm{v}+\mathrm{m})$ har bestått av 6 enheter av produksjonsmidler for lite til å kunne fullføre en rekonstruksjon av den konstante kapital II.

Den modifikasjon av skjemaets verdistørrelse som her blir aktuell, er dermed den som innebærer en økning av vareverdien I $(\mathrm{v}+\mathrm{m})$ med 6, det vil utifra Marx' talleksempler si en $\varnothing$ kning til 2006(v+m) før noe bytte mellom sektorene finner sted. Av »proporsjonalitetsgrunner « vil dette si en like stor $\varnothing \mathrm{kning}$ av både v- og m-del, slik at en får 1003Iv + 1003Im. Følger man proporsjonalitetsreglene videre, finner man at dette vil innebære en $\varnothing$ kning av k-delen med 12 (ettersom verdisammensetningen i skjemaet er 4), slik at forholdet mellom sektorene, innbefattet deres innbyrdes bytte, blir

$$
\text { I } 4012 \mathrm{k}+\underbrace{1003 \mathrm{v}+1003 \mathrm{~m}}_{\text {II } \ldots \ldots \ldots \ldots \ldots \ldots \ldots . . . . . .2000 \mathrm{k}+500 \mathrm{v}+500 \mathrm{~m} .}
$$

Verdimessig sett foreligger det her et ulikt bytte mellom sektorene, og dette administreres ved tesaurering i sektor II. Materielt sett er da derimot byttet tvert om likevektig, idet det er kompensert for de 6 enheter som produseres innen Ig uten å gå til noe materielt formål. Samtidig har det kunnet sted en $\varnothing \mathrm{kning}$ av den konstante kapital I med 12, dvs. med det relativt tilsvarende antall som forblir innen Ik.

Resultatet - som vi mener Marx må ha antesipert i og med at han må ha vært seg bevisst den truende krise som følge av overføringene mellom IIk og IIm - er i sum bare at introduksjonen av analysen av pengeproduksjonen i skjemaene må innebære et verditilslag til produktverdien, lik den sum gull som går til uproduktive formål. Dette tilslag må vedkomme sektor I, som produserer det angjeldende metall. Forutsatt at forholdet mellom den mengde av det nyproduserte gullmateriale 
som går til sirkulasjonsmidler og den som går til materiell produksjon holder seg konstant gjennom produksjonsperiodene (en forutsetning som ikke er strengere enn mange andre som det opereres med i skjemaene) kan den enkle reproduksjon fortsettes uavbrutt i dette justerte skjema.

\section{Historisk og begrepsmessig overgang}

Underavsnitt XII i analysen av enkel reproduksjon synes dermed å oppløse den mulige skranke kapitalakumulasjonen kunne møte i det begrensede antall ekvivalenter. Løsningen er ikke kunstig, da den fullt ut er forenlig med den enkle reproduksjon og følgelig med forholdene forut for enhver akkumulasjon. Derimot er det nærliggende å peke på i hvor liten grad det er mulig for det nyproduserte gullet å trenge seg fram til å overta plassen til det utslitte pengemateriale: For det første sirkulerer den mengde som går til II bare direkte over i lommene til kapitalistene II. For det andre begrenses den tilsvarende mengde i sektor I til å sirkulere produksjonsmidler som byttes mot sirkulasjonsmidler.

Dette er begrensninger som gir seg av at gullproduksjonen nødvendigvis er privatproduksjon, slik at det ikke finnes noen grunner til at gullgraveren skal gi fra seg sirkulasjonsmateriale uten å få umiddelbare gjenytelser, gjenytelser hvis naturskikkelse begrenser områdene for det nyproduserte gullets mulige baner innen den sosiale reproduksjon. (Det kan være god grunn til å tro at det har vært dette forhold som har foranlediget Grossmanns voldsomheter mot Marx' tekst). Etter vår oppfatning har Marx bare villet vise at mens den enkle reproduksjon $p \stackrel{a}{a}$ den ene siden i seg selv fører til opphopning av overskytende ekvivalenter som vil komme til nytte ved akkumulasjonen, så er den på den andre siden dårlig egnet til å spre de nyproduserte ekvivalenter på en slik måte at de kommer alle del-aggregater til gode. En slik spredning kan egentlig først komme ved akkumulasjonen, som »myker opp« bruken av alle aggregater hva angår deres muligheter for gjensidige verdioverføringer. »Penger«, lærte allerede Bacon oss, »er som gjødsel, de duger ikke til annet enn å bli spredt. $\ll^{86}$ (Grossmann ser derimot ut til å ha betraktet den begrensede sirkulasjon innen enkel reproduksjon som et argument for å introdusere for sterke elementer av planmessighet i den kapitalistiske produksjon.)

Og plaseringen av de overskytende ekvivalenter er den gunstigste hvis en tar utgangspunkt i behovet for en akkumulasjon. I sektor II er de tesaurert i merverdien år for år og danner således en vilkommen mulighet også til å igangsette akkumulasjon, ved at de kan benyttes til overføring av konsummidler til IIv 
som ledd i en økning av den variable kapitals størrelse (på relativ bekostning av merverdiens) i denne sektoren. Likeledes i I, hvor en må gå ut fra at den sirkulerende pengemengde innen aggregatet Ik av førnevnte grunner kontinuerlig vil være større enn nødvendig for enkel reproduksjon i dette aggregatet isolert sett. Selv om det riktignok er slik at tesaurering her ikke finner sted, er det rimelig å tenke seg at kapitalister I som er i ferd med å gå til innkjøp av fast kapital med bakgrunn i opphopne pengefonds fra tidligere produktsalg, vil kunne bli stimulert, av de økte pengemidlers nærvær, til å la dette kjøpet bli så omfattende at det sprenger rammene for den enkle reproduksjon. De materielle muligheter og betingelser for et slikt kjøp $\varnothing$ kes på sin side ved at de foreliggende ekvivalenter styrker andre kapitalisters Antizipationen der Wahrnehmung om at de vil kunne få avsatt et større produkt enn tidligere. Tvangen til relativ overproduksjon som følge av den kontinuerlige krise i den enkle reproduksjon på grunn av fornyelsen av den faste delen av IIk, sørger for at det ikke er påkrevd med noen større grad av bevissthet og apperseptiv målrettethet for å få resultatet i stand. (Selv om vi nedenfor skal komme tilbake til en mer grunnleggende forklaring av hvilke faktorer som teller sterkest ved spranget fra enkel til utvidet reproduksjon). Samtidig er det av betydning at Ik er nettopp det aggregat hvor akkumulasjonens objektive substrat (produksjonsmidler for produksjonsmidler) produseres, noe som kan lede til at I akkumulerer uten bistand fra II (hvor akkumulasjonens subjektive substrat indirekte blir produsert samtidig med $\varnothing \mathrm{kt}$ produksjon av levnedsmidler som kan kjøpes av variabel kapital), da mulighetene for intensivering av arbeidet innen visse grenser er uavhengige av stigning i realløn.

Vi har her holdt oss til et par akkumulasjonsmuligheter som Marx skisserer i kap. 21 - »Akkumulasjon og utvidet reproduksjon « - for sektor II og sektor ${ }^{87}$, og skal forøvrig innskrenke oss til å peke på den betydelige oppmerksomhet Marx i dette høyst ufullendte kapitlet vier såvel gullgraverne som den faste kapital II og dens fornyelse. Vi er beredt til å holde dette for å kunne innebære at en kontinuerlig overgang fra kap. 20, avsnittene XI og XII, til kap. 21 har vært på tale. Det kan nevnes at det her dreier seg om tekster som utelukkende stammer fra Marx' manuskript nr. VIII. Det siste avsnitt i 20. kapitel i den versjon av bd. II som Engels satte sammen, nemlig XIII, »Destutt de Tracys reproduksjonsteori«, er et rent »Beispiel « uten »tekstimmanens « (men dets plasering overensstemmer med Marx' tendens til å avslutte kapitler og verker med en »historisk-kritisk « del) og stammer forøvrig fra manuskript nr. II.

De emner vi har behandlet i punktene IV og V viser hvordan den enkle, kapitalistiske reproduksjon er en umulighet - men dette resultat oppnåes på denne reproduksjons egne premisser, noe som er en nødvendighet hvis formålet er vitenskapelig å vise at akkumulasjonen er en objektiv nødvendighet uavhengig av den enkelte konkurrerende kapitalists antesipasjoner om markedsutvidelser, og i det hele tatt uavhengig av konkurransen. (Et forhold som nettopp tilsløres av den form for

87. Jfr. respektivt s. 517f. (avsnitt IV) og 488ff. (avsnitt I). 
overgang mellom bd. II og bd. III som vi i dag kjenner.) Idet den enkle reproduksjon på denne måten analyseres som en del (som Marx sier) av den utvidende, så er dens status i realiteten å være en stående forklaring på hvorfor akkumulasjonen alltid er forutsatt i den kapitalistiske virkelighet (Wirklichkeit), »alltid allerede« er tilstede. Det samme vil a forteriori - og nettopp dét aspektet er det viktig å betone i vår sammenheng - gjelde for profittratens (m.m.) »tilstedeværelse«. For alt i alt vil profittraten for oss kvalitativt sett bli å betrakte som en »funksjon « av akkumulasjonen (som i realiteten også for Schanz). Men ettersom profitten og dens medfølgende kategorier, såsom grunnrenten ${ }^{88}$ som tidligere (jfr. særlig avsnitt I) nevnt i sin tur alltid allerede innebærer at kapitalens totalitet er nådd, vil vår fremstilling være ufullstendig om vi ikke også hadde utviklet totaliteten $i$ den enkle reproduksjon (nemlig som en forklaringsforutsetning for den totalitet som gir seg av denne reproduksjons sprengning). Denne totalitet er ikke ganske enkelt sammenfallende med den enkle reproduksjon som totalitet, dvs. med den enkle reproduksjon som enkel enhet av produksjons- og sirkulasjonsprosess. Tvert om må også didsse prosessers forutsetninger reflekteres inn.

For dette formål kan vi gå tilbake til Marx' betraktninger over analysen av gullets reproduksjon. Vi mener disse betraktninger holder stikk også etter unders $\emptyset$ kelsen av Ikg, da det potensielt kontinuerlig økende volum av ekvivalenter i omløp innen Ik forsåvidt også er en »Aufspeicherung « eller »magasinering «.

Som fremhevet, understreker Marx hvordan »pengemagasinering eller tesaurering « (Geldaufspeicherung oder Schatzbildung) »nødvendig « er innbefattet i den enkle reproduksjon. Han fortsetter: ${ }^{89}$

»Og da dette gjentar seg påny år etter år, så forklares også den forutsetning som det utgåes fra ved betraktningen av den kapitalistiske produksjon: at det ved reproduksjonens begynnelse befinner seg en mengde av pengemidler, svarende til vareomsetningen, i hendene på kapitalistklassene I og II. Slik magasinering finner sted selv etter fradrag av det gull som går tapt ved slitasje på de sirkulerende penger.«

Man ser: der dreier seg her ikke bare om å vise hvordan den skranke som mangelen på ekvivalenter (jfr. avsnitt II, ovenfor) ville utgjøre, »alltid allerede « er opphevet. Det dreier seg også om å vise hvordan reproduksjonen ipso facto og samtidig totaliseres, idet analysens endepunkt faller sammen med dens utgangspunkt, i den betydning at det forklarer det. Vi vil i denne sammenheng legge særlig vekt på at Marx’ resultat også lar seg tolke som den fundamentale rettferdiggjøring og konkretisering av analysen av den enkle reproduksjon i bd. I. At det kan vises at det på kapitalistisk basis kan forutsettes at det finnes tilstrekkelige midler til vareomsetningen, innebærer at det også kan vises at kapitalisten(e) i utgangspunktet på

88. Sagt på én måte er jo nemlig forskjellen mellom på den ene side bindene I og II, på den andre bind III, at i de to første behandles merverdien uoppdelt og »uavhengig av sine former «, mens bd. III nettopp utgår fra merverdiens »deling « og formdannelse: dens 'spaltning' i rente, entreprenørgevinst, osv.

89. Das Kapital, bd. II, s. 469. 
kapitalistisk basis kan betraktes som »pengebesitter(e)«. Man hverken må eller kan altså lenger forutsette at »kapitalisten en eller annen gang ble gjort til pengebesitter gjennom en eller annen opprinnelig akkumulasjon som var uavhengig av fremmed, ubetalt arbeid. «(Jfr. avsnitt III, ovenfor.)

Også en mer generell forutsetning for bl.a. reproduksjonsskjemaene, nemlig at de utgår fra eksistensen av bare to sosiale klasser (arbeidere og kapitalister) er dermed rettferdiggjort. Reproduksjonsanalysen viser seg å være ikke bare geografisk (en sluttet nasjonaløkonomi), men også historisk »lukket«. At det på denne måten kan vises hvordan det ved slutten av bd. II foreligger et helt skjelett til den totalitet som, ifølge Marx i 1858, i »virkeligheten « blir produsert av kapitalen via dens egen vekselvirkning med grunneiendommen og som en produksjon av lønnsarbeidet via grunneiendommen, understreker at Grossmann igjen tar feil når han hevder at Marx' hovedpoeng skulle bestå i å vise at det opp igjennom »middelalderen « må ha opphopet seg såpass mye gull at kapitalen forsåvidt ikke har vansker med å tre inn på den historiske scenen. ${ }^{90}$

Marx' resultat har tvert om å gjøre med en demonstrasjon av det kapitalistiske systems evne til selvreproduksjon. Og denne autoreproduksjon er fra nå av noe ganske annet enn den vi finner i første bind, og som bare er holdt sammen av lønnsarbeideren. Tvert om er forutsetningen for analysen i bd. I påvist som noe som ligger »forut « for den lønnsarbeider vi møter i den samme analyse. Dette »forut « har vist seg å kunne fremgå av en allerede kapitalistisk reproduksjon. - Samtidig har det vist seg at (det formelle) resultatet av samme analyse, d.e. at kapitalens opprettholdelse faller sammen med dens størrelses $\varnothing$ kning, bare kan forsvares dersom en trekker inn i vurderingen den skranke som ligger i de begrensede mulighetene for konsum (produktivt eller individuelt) av de gitte bruksverdier. Denne skranke betraktes mest konkret ved erstatningen av den faste kapital, samtidig som skrankens relativitet (dvs. at den er skranke og ikke grense) umiddelbart vises: akkumulasjon tvinges fram, og en får en kontinuerlig relativ økning av konsummulighetene.

Gjennom denne utvikling av den enkle reproduksjon, av den »rene gjentakelse« av prosessen, har subjektene følgelig skiftet plass: det har vist seg hvordan det ikke lenger er arbeideren, men tvert om kapitalisten, som initierer reproduksjonsprosessen. For grunnen til at den rene gjentakelse overhodet finner sted, viser seg å ligge i kapitalens akkumulasjon, styrt av kapitalisten. Samtidig må derfor også det nye subjektets form, nemlig profitten, dukke opp. Som nevnt må dette skje i gjennomsnittsprofittens skikkelse.

Denne utviklingen av totaliteten i emner fra såvel bd. I som bd. II gjør det passende å illustrere tankegangen med et skjema (jfr. s. 45) for den aktuelle og potensielle oppbygging av Das Kapital. Dette desto mer som den nevnte totalitet nettopp »sprenger seg selv« og så å si vrenger sitt indre opp som et konkret-sammensatt

90. Jfr. op.cit. 1932, s. 103. Selvsagt er denne forestillingen enda mer forkastelig idet reproduksjonsskjemaene jo er bygget for allerede kapitalistiske forhold. Tesaureringsresultatet er f.eks. umulig uten å forutsette kapitalistisk privateiendom og eksistensen av variabel kapital. 
overflate, dvs. produksjonssystemet slik det er »i virkeligheten « og i helheten: »den kapitalistiske produksjons totalprosess«, slik den behandles i bd. III:

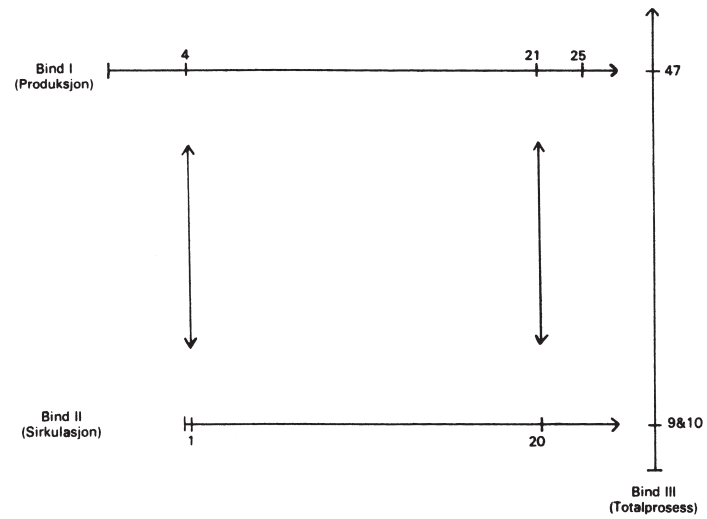

Kapitler i de forskjellige bind betegnes av tallene langsmed pilene. De forskjellige binds gang fra første til siste kapitel er symbolisert ved hovedpilenes retning. »Retningen « for bd. III går på tvers av den som gjelder for bindene I og II. Dette er egnet til å betegne noe vi flere ganger aksessorisk har pekt på, nemlig at dette bindet, fordi det behandler forholdene slik de er »in der Wirklichkeit (d.h. in der Erscheinungswelt) « ${ }^{91}$, fremstillingsmessig bryter over tvert med bd. I-II. Dette peker i sin tur på at det faktum at de to første bind begge ligger på verdiplanet, indikerer en grunnleggende parallellitet mellom dem, en parallell som forøvrig innebærer at det $\mathrm{i}$ en viss forstand ikke er riktig å tale om noen »overgang « dem imellom, noe vi har forsøkt å få fram i dette innlegget. De to bindene utfyller hverandre heller kontinuerlig; det er så å si bare analytisk at de foreligger atskilt. Parallelliteten viser seg f.o.m. kapital 4 i bd. I, »Forvandling av penger til kapital«, idet det jo først er fra dette punkt at en kapitalsirkulasjon kommer inn i bildet. Det bør i denne forbindelse nevnes at Marx selv kalte de første kapitlene i bd. I for »vorchapters « dvs. »forkapitler « til fremstillingen av kapitalen. Den vertikale pil fra bd. I,4 til bd. II,1 er ment å skulle få fram disse forholdene. Den tilsvarende pil fra bd. I, 21 til bd. II, 20 skal dels fremheve den gjensidig utfyllende valør som finnes i kapitlene om den enkle reproduksjon i de to bind; i så måte er den ment å dekke både relasjonen mellom den pengebesittende kapitalist i bd. I og reproduksjonen av pengematerialet i bd. II, og påvisningen av at all kapital må bli til kapitalisert merverdi (bd. I) og analysen av den faste kapital (bd. II). Dels skal den også fremheve at stoffet i III. avsnitt av bd. II (reproduksjonsskjemaene) er av en slik karakter at det ikke lenger bare er tale om en parallellitet, men om en enhet av produksjon og sirkulasjon som gjennom sine motsetninger fremtvinger profitten og dens former. Denne enhet aktualiserer den egentlig første »overgang« innen Das Kapital, om

91. Das Kapital, bd. III, s. 57. 
en tilnærmet tar ordet i den forstand Schanz bruker det. Det viser seg at den i så måte faller sammen med en overgang fra verdi- til prisplan. Denne overgang tar tematisk opp i seg de bestemmelser som atskiller produksjonen fra sirkulasjonen (Entwertungs-problemet med ekvivalent- og konsumskrankene) og viser dermed implisitt hvordan enheten mellom produksjon og sirkulasjon er av en så different art at profittformen og totalprosessen må introdusere seg selv. Denne overgang har vi fremstilt fra bd. II, 20 til bd. III, 9, nemlig kapitlet »Gjennomsnittsprofittrate og produksjonspriser «. Årsaken til dette ligger dels i det vi - på slutten av punkt II har nevnt om reproduksjonsskjemaenes total-sosiale sammenheng. Men nettopp på grunn av den konsumskranke som derfor er inne i bildet, må bd. III, 10 også trekkes inn. Dette kapitlet, »Utjevning av den allmenne profittrate gjennom konkurransen. Markedspriser og markedsverdier. Surplusprofitt «, betrakter nemlig verdibestemmelsen nettopp utifra den modifikasjon som kommer til å gjelde for den når konsumskrankene introduseres. Kapitlet er derfor et nødvendigt ledd i en fremstilling av hvorfor (gjennomsnitts)profitten nettopp får status av et mål (Mass). ${ }^{92}$

- Men dels ligger grunnen til overgangen fra bd. II, 20 til bd. III, 9 \& 10 også $\mathrm{i}$ at sprengningen av den enkle reproduksjon med dens disproporsjonalitet er den grunnleggende forklaring av og forsikring om at vi i det kapitalistiske systemet nødvendigvis er henvist til et system av enkeltkapitaler, som definerer seg i forhold til hverandre i kraft av variasjonene i bytteratene (produksjonsprisene) ${ }^{93}$ som hersker dem imellom. Forholdet $\mathrm{I}(\mathrm{v}+\mathrm{m})=\mathrm{IIK}$ er nettopp en slik bytterate in embryo, om en tenker inn i den den disproporsjon den vil uttrykke såsnart produksjonen innen hver av sektorene begynner å gå uproporsjonert. Om en tenker seg disse bytteforholdene oversatt til et akkumulerende system, vil de faktisk allerede ha karakter av produksjonspriser. ${ }^{94}$

Denne antakelsen er vunnet på bakgrunn bl.a. av at en anerkjennelse av at et proporsjonalt bytteforhold såsom $\mathrm{I}(\mathrm{v}+\mathrm{m})$ = IIk på forhånd forutsetter den modifiserte verdibestemmelse, og således konsumskrankene, i form av et krav om begrensning av de bruksverdimengder som kan inngå i de forskjellige aggregater samtidig som de gjør krav på å være bærere av verdi. ${ }^{95}$

92. V.S. Vygodskij forsøker (Die Geschichte einer grossen Entdeckung, utg. Berlin 1967, kap. 6) å vise overgangen fra verdi til produksjonspris ved hjelp av Marx' kategori om den »falske sosiale verdi«, som er nært knyttet til den nevnte modifikasjon av verdibestemmelsen. Det etter vårt skjønn ikke helt tilfredsstillende ved hans fremstilling kunne ha vært bøtet på om han hadde trukket forbindelsen fra reproduksjonsanalysen til mål-kategorien.

93. De omtalte »variasjoner er altså det samme som konkurransen disse kapitalene imellom.

94. En kan se på den fysisk/verdimessige disproporsjon som - ifølge våre fremstilling i punkt V C - foreligger i sektorbyttet allerede som konsekvens av introduksjonen av gullgravingen, som en forutskikkelse av dette.

95. Man ser her kanskje klarere enn andre steder hvordan et slikt »krav« faller sammen med at aggregatene i praksis kan byttes, og altså inngå i konsum. Den modifiserte verdibestemmelse understreker bytteverdien som verdiens (nødvendige) Erscheinungsform. Det umiddelbare, nye uttrykk for en slik form er ganske riktig profitten, som nettopp på denne måten selv antar karakter av Erscheinungsform. Denne karakter kan den altså ikke ha uavhengig av dens særlige mål-karakter. 
Kapitlene 1-8 i det nåværende bd. III må oppfattes som analytiske »vorchapters « hvis formål er å »oppdele«, »analysere«, en allerede foreliggende gjennomsnittsprofitt. De kan ikke på noen måte regnes som genetiske. Qua analytiske kan de sies å unders $ø$ ke hver enkeltkapitals utseende og vandel $i$ kapitalakkumulasjonen. Som sådanne kan de også være til nytte i analysen av den utvidede reproduksjon $\mathrm{i}$ bd. II, 21. For selv om analysen der foregår på verdiplan, kan den ikke skille seg vesentlig fra bd. III, 1-8, idet verdistørrelser også der forutsettes; det eneste nye som skjer, er at profitten oppstår ved at merverdien subjektivt relateres til hele kapitalen.

På bakgrunn av alt som her er sagt, som jo impliserer at akkumulasjon og profitt gjensidig forutsetter hverandre, kunne man fristes til å foreslå at Marx burde ha plasert samtlige av sine »akkumulasjonskapitler« i bd. III. ${ }^{96}$ Det er fruktbart å lufte noen motforestillinger overfor en slik oppfatning, som - kan det være grunn til å tro - overser arbeidernes, det »subjektive substrats « betydning for akkumulasjon og profitt.

Denne betydnings vekt hos Marx indikeres av hvordan kjernen i akkumulasjonsfremstillingen i bd. I, nemlig kapitel 23, »Den kapitalistiske akkumulasjons allmenne lov«, uttrykkelig bare vil behandle »den innflytelse som kapitalens vekst utøver på arbeiderklassens situasjon $\ll{ }^{97}$ Den kan i det hele tatt bare fremstilles adekvat innen en studie av kapitalens produksjonsprosess, hvor arbeidernes umiddelbare stilling først kommer til syne. Den reproduksjonsskjematiske fremstilling i bd. II trekker riktignok bruksverdibetraktningen inn ved siden av verdibetraktningen, men bare som ferdig produserte bruksverdier som bærere av produktverdier. Produksjonens ene element, arbeiderne og/eller arbeiderklassen får altså ikke analysert sin vekselvirkning med det andre element, produksjonsmidlene, i deres skikkelse av konstant kapital, innen reproduksjonsskjemaene.

Det er egentlig denne vekselvirkning som er hovedtema i akkumulasjonskapitlene i bd. I, idet den faller sammen med selve begrepet om kapitalens organiske sammensetning. ${ }^{98}$

For å få fram betydningen av dette for vårt formål kan vi vise til hvordan vi ovenfor, ved fremvisningen av utgangsbetingelsene for akkumulasjon i skjemaene, for den subjektive faktors vedkommende bare måtte henvise til at »mulighetene for intensivering av arbeidet innen visse grenser er uavhengige av stigning i realløn «. Dette er riktig nok, og også viktig nok sett ut fra den for reproduksjonsskjemaene selvfølgelige forutsetning at arbeiderbefolkningen er konstant, slik at $\varnothing \mathrm{kt}$ produktivitet hos de forhåndenværende arbeidere er en betingelse for overgang til akkumulasjon.

Men det er klart at det fordres en forutgående unders $ø$ kelse av mulighetene for og følgene av slik intensivering, for det første fordi den allerede vil være ensbe-

96. Dette anbefales forøvrig av Makato Itoh, $\mathrm{i} »$ The formation of Marx' Theory of Crisis«, CSEB, Vol. IV.1, London 1975. Senere trykt i Kurasje.

97. Das Kapital, bd. I, s. 640.

98. Som en bevegelig enhet av teknisk (Pm:A) og verdimessig (k:v) sammensetning av produksjonens subjektive og objektive elementer. Jfr. ibid. 
tydende med akkumulasjon, altså med det tema som står til undersøkelse. Og for det annet dreier det seg om en akkumulasjonsform som ikke kan analyseres ut fra situasjonen i skjemaene, idet det allerede forutsetter en spesiell form for vekselvirkning såvel mellom (k:v) og (Pm:A) som mellom komponentene innen disse to sammensetningene selv.

Saken er nemlig at det på den enkle reproduksjons nivå ikke løser noe som helst problem å forlange en intensivering av arbeidet. For det kan aldri foreligge noen materialer (produksjonsmidler) som kan være gjenstand for intensiveringen, dvs. for det $\varnothing \mathrm{kte}$ kvantum arbeid som må forutsettes utgitt i forhold til arbeidsmengden i foregående periode. Slike materialer må ut fra skjemaenes situasjonsbeskrivelse oppfattes som arbeidsmidler og råstoffer som kommer i tillegg til forrige års produksjon, og således forutsette at akkumulasjon allerede hadde funnet sted (uendelig regress).

Det er klart at det i denne henseende er reproduksjonsskjemaene som er »formelle « $\mathrm{i}$ forhold til analysen i bd. I, og det er hit vi må tilbake for å finne en reell løsning. Samtidig er det klart at en slik reell løsning må abstrahere fra det moment man er vant til å anse for det kanskje mest karakteristiske ved akkumulasjon, nemlig merverdiens deling i konsumfond (inntekt) for kapitalisten på den ene siden, og i investeringsfond (kapital) på den andre. Utifra vårt foreløpige nivå ville en slik deling innebære et utvidet marked, slik at den enkle reproduksjon allerede ville være forlatt. I alle fall må vi bortse fra eksistensen av noe investeringsfond til produksjonsmidler. Fondet kan i høyden benyttes til økte utbetalinger til de tilstedeværende arbeidere, som »kompensasjon« for $\varnothing \mathrm{kt}$ arbeid (altså: $\varnothing \mathrm{kt}$ reallønn) og tilsvarende redusert konsumvareetterspørsel fra kapitalistene, slik at markedet ville forbli stabilt. Men altså: hvor ligger de stofflige betingelser som 1) gir anvendelsesmulighet for dette tilleggsarbeidet og 2) hvis eksistens allikevel er i overensstemmelse med skjemaenes forutsetninger?

Nå angår akkumulasjonsanalysen i bd. I som sagt vesentlig bl.a. vekselvirkningen mellom arbeidere og produksjonsutstyr, sett dels fra verdiside og dels fra bruksverdiside. Som sådan vil den alltid inkludere disproporsjonalitet mellom disse faktorene i forhold til deres tilnærmede proporsjonalitet på et annet tidspunkt. Den vil mao. innbefatte en påstand om at disproporsjonen innenfor selve den kapitalistiske arbeidsprosess er et så »vesentlig « element at den proporsjon som hersker mellom dem i skjemaene i seg selv inkluderer disproporsjon og dynamiske muligheter for akkumulasjon. Det er derfor egentlig slik at hele analyseformen i bd. I, hvis den er tilpasset objektet, vil være egnet til å oppløse den problemstilling vi har for oss. Ettersom vi imidlertid - i det minste i utgangspunktet - må abstrahere fra merverdiens deling, ser vi først og fremst på bd. 1, 22 (»Forvandling av merverdi til kapital«), fjerde avsnitt, som behandler »Omstendigheter som bestemmer akkumulasjonens omfang uavhengig av merverdiens proporsjonelle deling i kapital og inntekt. «99

99. Jfr. Das Kapital, bd. I, s. 625. 
Som det fremgår, er akkumulasjonen og merverdidelingen her allerede forutsatt som analysegjenstand. Ikke desto mindre er det å vente at avsnittet vil gi meldinger om akkumulasjonsmuligheter under abstraksjon fra delingen, iallfall hva gjelder fra investeringsfonds til produksjonsmidler. Dette desto mer som det dreier seg om å få fram at kapitalistene får visse berikelseskilder »gratis« og dermed uavhengig av delingens proporsjoner. En del av disse gratiskilder er riktignok aktuelle først på bakgrunn av allerede igangsatt akkumulasjon. ${ }^{100}$ Men de av dem som ser ut til å være de mest fundamentale, er uavhengige av en slik forutsetning.

Marx anfører tre eksempler, hvorav de to første, som omhandler generelle tilfelle fra kapitalistisk drift av ekstraktiv industri og av jordbruk, tjener til å konstruere det tredje, som er hentet fra den alminnelige industri: ${ }^{101}$

»I den ekstraktive industri, f.eks. bergverk, danner råstoffene ingen bestanddel av den forskotterte kapital. Arbeidsgjenstanden er her ikke produkt av tidligere arbeid, men forært gratis av naturen. Slik er det med malm, mineraler, steinkull, stein etc. Den konstante kapital består her nesten utelukkende av arbeidsmidler, som meget godt kan tåle et utvidet arbeidskvantum (dagog nattskift av arbeidere f.eks.). Men om alle andre omstendigheter forutsettes like, vil produktets mengde og verdi stige direkte i forhold til det anvendte arbeid. Som produksjonens første dag, smelter her de opprinnelige produktskapere, og dermed også skaperne av kapitalens stofflige elementer, menneske og natur, sammen. Takket vare arbeidskraftens elastisitet har akkumulasjonsområdet utvidet seg uten forutgående фkning i den konstante kapital.

I landbruket kan man ikke utvide dyrkningsjorden uten forskottering av ytterligere såkorn og gjødsel. Men når denne forskottering engang er foretatt, vil selv en rent mekanisk bearbeidelse av jorden ha en vidunderlig virkning på produktmengden. Et utvidet arbeidskvantum, utført av det hittidige antall arbeidere, vil dermed $\varnothing \mathrm{ke}$ fruktbarheten uten å kreve en ny investering i arbeidsmidler. Igjen er det menneskenes direkte virkning på naturen som blir til en umiddelbar kilde til økt akkumulasjon, uten en ny kapitals mellomkomst.

Endelig: i den egentlige industri vil hvert ytterligere arbeidsutlegg forutsette et ytterligere tilsvarende utlegg til råstoffer, men ikke nødvendigvis også til arbeidsmidler. Og da ekstraktiv industri og landbruk leverer sine egne og sine arbeidsmidlers råstoffer til den bearbeidende industri, vil også denne nyte godt av den produkttilvekst som den førstnevnte har skapt uten ytterligere kapitaltillegg.

Det allmenne resultat er: Idet kapitalen innforliver i seg rikdommens to urskapere, arbeidskraft og jord, erhverver den seg en ekspansjonskraft som tillater den å utvide sin akkumulasjon over de grenser som tilsynelatende er satt av dens størrelse, satt av den verdi og den mengde av allerede produserte produksjonsmidler som den eksisterer i.«

De her beskrevne forhold er sett fra én synsvinkel å betrakte som videreføringer av det generelle faktum at all kapitalistisk verdiproduksjon foregår via en sammensmeltning av subjekt og objekt som kapitalisten tilegner seg uten vederlag. ${ }^{102}$ Men det er spesifikt for dem at de ikke bare foregår »ved siden av« og som betingelse for verdiproduksjonen (også som betingelse for en verdiproduksjon som

100. Det dreier seg her i første rekke om $ø$ kningen i det samfunnsmessige arbeids produktivkraft og om naturvitenskapelige fremskritt.

101. Das Kapital, bd. I, s. 630f. Uthevet her.

102. Pregnant uttrykt i Grundrisse (s. 269): »I produksjonsprosessen er arbeidets atskillelse fra sine gjenstandsmessige betingelser (Daseinsmomenten) - instrument og materiale - opphevet. Kapitalens og lønnsarbeidets eksistens (Dasein) beror på atskillelsen. Atskillelsens oppphevelse, som virkelig foregår i produksjonsprosessen - for ellers kunne det overhodet ikke arbeides - betaler kapitalen ikke." 
kunne tenkes i utgangspunktet å være 'proporsjonell' med bruksverdiproduksjonen, slik som i reproduksjonsskjemaenes enkle reproduksjon), men også som en indre overskridelse av de ideelle og kalkulerbare faktorer ved verdiproduksjonen. Det dreier seg om bruksverdiproduksjon uten »proporsjonell« bakgrunn i tidligere verdiproduksjon, idet arbeidet foregår direkte på det opprinnelige objekt, - det mangfoldige objekt slik det foreligger før det blir organisert av skjemaet. Ikke bare dreier det seg om forhold som er de eneste som kan gi en arbeidsintensivering (eller liknende) forklaringsrelevans ved en overgang til akkumulasjon fra enkel reproduksjon totalt-sosialt sett, ettersom de ikke nødvendiggjør tilstedeværelsen av nye »overskytende« produserte produksjonsmidler; det dreier seg også - etter vår oppfatning - om forhold som er konstituerende for verdiens overgang til produksjonspris og dermed for merverdiratens forvandling til allmenn profittrate. (At de fyller et naturlig »tomrom « $\mathrm{i}$ reproduksjonsskjemaenes selvsprengning til akkumulasjon, er derfor spesielt tankevekkende.) Hovedpoenget i denne siste forbindelse som vi her desverre ikke kan utvikle i detalj - ligger bare $i$ at en slik overgang synes å kunne være betinget allerede av motsetninger i den umiddelbare produksjonsprosessen, ettersom det her viser seg at kapitalens bemektigelse av komponentene $\mathrm{i}$ den »opprinnelige« subjekt-objekt-relasjonen (»arbeid og jord«) får konsekvenser som divergerer med verdiproduksjonens og verdimålingens vanlige leie i forhold til den gitte kapital. I bd. II kommer Marx tilbake til emnet ved å vise til at »det ble vist i første bok at en gitt kapitals virkningsgrad er betinget av potenser i produksjonsprosessen, som i en viss grad er uavhengige av dens egen verdistørrelse.« Han fortsetter med å vise til at det i bd. II utvikles at »sirkulasjonsprosessen setter i bevegelse nye potenser for kapitalens virkningsgrad og dens ekspansjon og kontraksjon, uavhengig av kapitalens verdist $\varnothing$ rrelse. $\ll^{103}$ Det ser her i det vesentlige ut til å dreie seg om forhold angående kapitalomslaget, som ifølge Marx ${ }^{104}$ er den faktor ved siden av arbeidslønnen som må fremstilles for å kunne introdusere gjennomsnittsprofitten. ${ }^{105}$ I virkelighetens verden dreier det seg selvsagt også om de faktorer som vil virke på samme måte som de her nevnte først etter at akkumulasjon er igangsatt. Særlig må her nevnes $\emptyset$ kningen i det samfunnsmessige arbeids produktivkraft og virkninger av vitenskapen som produktivkraft. ${ }^{106}$. Hva gjelder de potenser i produksjonsprosessen som muliggiør overgang til akkumulasjon, må vi derimot selvsagt holde oss til de som er forenbare med en utgangssituasjon preget

103. Sitater fra Das Kapital, bd. II, s. 45 f.

104. Jfr. brev til Engels nevnt i note 34, ovenfor.

105. Angående mulighetene for at denne profitt får sin »oppkomst« forklart gjennom reproduksjonsskjemaene, er det verdt å legge merke til at krisen i den enkle reproduksjon »begrepsmessig « innbefatter spørsmålet om kapitalomslaget, idet dette i det vesentlige har å gjøre med forholdet mellom fast og flytende kapital.

106. »Man har videre sett hvordan den arbeidskraft, vitenskap og jord (hvorved økonomisk forståes alle de arbeidsgjenstander som fra naturens hånd er tilstede uten menneskelig inngrep) som innforlives $\mathrm{i}$ den fungerende kapital, utgør elastiske potenser for den selv når dens størrelse er gitt, potenser som gir den et spillerom som innen visse grenser er uavhengig av dens egen størrelse.« (Das Kapital, bd. I, s. 636). 
av enkel reproduksjon. Det som da i vår forbindelse er viktig å fastholde, er for det første at å beskrive disse potenser selvsagt er det samme som å beskrive akkumulasjon, samt for det andre at deres måte å virke på (i vekselvirkning med kapitalens verdisammensetning) er typisk for arbeidets og arbeidernes stilling innen akkumulasjonen overhodet.

Disse momenter er etter vår forståelse tilstrekkelige til å garantere akkumulasjonskapitlene en selvsagt plass innenfor fremstillingen av den umiddelbare produksjonsprosess. At vekten ligger på arbeidskraftens stilling, herunder det viktigste moment, konstruksjonen av den relative overbefolkning (industriell reservearmé) følger rimelig av at lønnsarbeidet gjennom den enkle reproduksjon som nevnt fungerer som et reservesubjekt. Holder man imidlertid i minnet hvordan fremstillingen konkretiseres ved at tvangen til akkumulasjon demonstreres i det parallelt løpende bd. II, blir det klart at arbeideren, såsnart han underkastes denne akkumulasjonen, ikke er noe »formalt« subjekt lenger. Ikke bare kapitalistens utnyttelse av arbeidskraftens elastisitet, men også den tvang som må legges for dagen for å gjennomføre denne produksjon av nyverdi så å si på tross av den eksisterende kapital, gjør det umulig å opprettholde en slik metodisk abstraksjon. Det er ingen tvil om at det dyriske kapitalsubjektet egentlig har overtatt, og samtidig er lønnsarbeidet forvandlet til et realt subjekt, men da også bare mhp. en annen samfunnsordning. Lønnsarbeiderens på denne måten reale underkastelse under kapitalen understrekes så av hvordan Wakefield-kapitlet skildrer ham som uløselig satt inn i en skruestikke mellom kapital og grunneiendom. Følgelig må vi - idet vi igjen retter oppmerksomheten mot den skjematiske fremstilling av de tre binds forhold til hverandre, ovenfor understreke at mens overgangene mellom bindene I, II og III bare i ett tilfelle også er av »teoretisk « eller »begrepsmessig « art, så finnes det flere logiske overganger i systemet. Som vi har villet vise i skjemaet, finnes det en overgang fra bd. I til (omtrentlig) bd. III, 47, »Den kapitalistiske grunnrentes genese «, i og med at dette kapitel avslutter læren om grunnrenten og dermed i realiteten innebærer at de faktorer som holder lønnsarbeiderne på plass i systemet er ferdigbehandlet. (Kapitlene 47-52, »Inntektene og deres kilder«, er å betrakte som »etterkapitler«. De bringer ikke inn noe nytt, men er konsentrert om å vise hvordan den erhvervede kunnskapen skal brukes til å trenge igjennom den allerede forklarte ideologiske overflaten. De fungerer som Kants »Transzendentale Methodenlehre«.) Men det er her bare berettiget å tale om en overgang såfremt det i bd. II gies bevis for at den akkumulasjon som unders $\varnothing$ kes i I, 22-23 er av nødvendig art. Det sikres da at den tvang til reproduksjon vi møter f.eks. i I, 21 utelukkende av fremstillingsmessige grunner er båret av lønnsarbeidere: det vil senere vise seg at en mer reell tvang ligger bak.

Det sikres med andre ord at den akkumulasjon som i konsekvens leder til produksjonen av en stigende jordpris, er like reell og total som vi uten videre ser at det er tilfellet med den utvidede reproduksjon i bd. II. Post festum blir det på denne måten også vist at systemet også er kjennetegnet av en serie $n \phi d v e n d i g e$ overganger mellom kategoriene lønnsarbeid, grunneiendom og kapital, om de nå kommer eksplisitt fram eller ikke. 
Av det vi har nevnt i avsnitt III, spesielt med hensyn til jordprisens funksjon, fremgår det at »In den ökonomischen Verhältnissen des modernen Grundeigentums, ... ist daher die innre Konstruktion der Modernen Gesellschaft, oder das Kapital in der Totalität seiner Beziehungen gesetzt.« Og det er selvsagt først som slik totalitet at kapitalen behersker samfunnet, samtidig som denne beherskelse er det vesentlige karakteristikum ved totaliteten. Det viser seg her en ytterligere »parallellitet «, nemlig mellom den logiske overgang og den historiske; kapitalens overgang i grunneiendommen er nemlig også en »overgang « til det eiendomsforhold (produksjonsforhold) som historisk var dominerende forut for kapitalen. Dermed er den også et skjema for kapitalens »overgang « til (utradering av) prekapitalistiske forhold innen sin midte overhodet.

Hvordan denne type historisk overgang nå blir fastholdt og understreket innen den begrepsmessige fremstilling selv, kan man se av enda en parallellføring mellom avslutningene av bd. I og bd. II - en parallellføring vi tar med for å bidra til en konkretisering av overgangskategorien, men som ikke desto mindre er »tekstimmanent $\ll$ nok.

Ovenfor har vi kort bemerket at krisen som skildres i bd. II, 20, XI tillegges stor vekt hos Marx. Dette har ikke minst forbindelse med historiske betraktninger. I dette avsnittet som i realiteten begrunner den kapitalistiske produksjons spesifikke differens overfor den foregående og etterfølgende historiske epoke, nemlig $a k k u$ mulasjonen, trekker han fram forholdet til det kommunistiske samfunn ved å vise til at den omtalte krise ${ }^{108}$

»bare kan avhjelpes gjennom en kontinuerlig relativ overproduksjon; på den ene side produksjon av et større kvantum fast kapital enn det som er direkte nødvendig. På den andre siden, og først og fremst, lagring av råstoffer osv. ut over det umiddelbare årlige behov (særlig gjelder dette for levnedsmidler). En slik art overproduksjon er lik med samfunnets kontroll over de gjenstandsmessige midler til dets egen reproduksjon. Men innenfor den kapitalistiske produksjonsmåte er den et anarkisk element.«

Det vil si, i det borgerlige samfunn må den ytre seg både som overproduksjonskrise og som kontinuerlig, relativ overproduksjon i spontan forstand. Vi har tidligere bare en passent streifet denne borgerlige forutskikkelse av markedsutvidelser, og hvordan den kan lede opp til akkumulasjon. Vi kan nå holde fast ved den, og se hvordan Marx utnytter den til å avgrense den kapitalistiske epoke også overfor dens forgjengere. I forbindelse med fremstillingen av differensialrenten nevner han at i landbruket såvel som i alle de øvrige kapitalistisk drevne bransjer ${ }^{109}$

»vil det kontinuerlig finne sted den type relativ overproduksjon som an sich er identisk med akkumulasjonen og som ved andre produksjonsmåter blir bevirket direkte gjennom befolkningsøkningen, og i koloniene gjennom kontinuerlig innvandring.«

107. Grundrisse, s. 187.

108. Das Kapital, bd. II, s. 465. Uth. her.

109. Das Kapital, bd. III, s. 685. Marx gjør en generell forutsetning om at landbruket er kapitalistisk. 
Når akkumulasjonen, som Marx kallder das Dasein des Kapitals ${ }^{110}$ her i realiteten blir parallellført med befolkningsveksten for tidligere samfunns vedkommende, så understreker det at nettopp akkumulasjonen differensierer det borgerlige samfunn til en særlig historisk epoke, og dermed også begrenser de førborgerlige samfunn til én slik epoke. Dette understrekes spesielt av tendenser til å gjøre befolkningsveksten - tilsvarende akkumulasjonen (det vil i praksis si produktivkreftenes tilsynelatende skrankeløse utvikling) for det borgerlige samfunns vedkommende - til determinant for den sosiale forandring, eller mangelen på slik forandring, i førborgerlige formasjoner; såsom når han uttaler: ${ }^{11}$

»Det gjelder for alle tidligere produksjonsformer at det ikke er produktivkreftenes utvikling som er basis for tilegnelsen (der Aneignung), men at en bestemt relasjon (Verhalten) til produksjonsbetingelsene (eiendomsformene) tvert om fremstår som en forutsatt skranke for produktivkreftene, og bare skal reproduseres; følgelig må befolkningsutviklingen, hvori utviklingen av alle produktivkrefter resymerer seg, i enda større grad forefinne en ytre skranke og altså fremstå som noe som må beskrenkes (als zu Beschränkendes erscheinen). Samfunnets betingelser er bare forenlige med en bestemt befolkningsmengde.«

Følgelig får en f.eks. utvandring som et »strukturelt« svar på truende kriser ${ }^{112} \mathrm{og}$ andre forhold som i kjerne er uforenlige med utviklet kapitalistisk produksjon. For denne siste er det tvert om slik at de tidligere samfunns spesifikke differens, befolkningsvariasjonene, er opphevet i og inneholdt i det borgerlige samfunns spesifikke differens. Vi har i dette innlegget ikke kunnet gå konkret inn på hvordan Marx demonstrerer dette ved å vise til hvordan kapitalen gjennom akkumulasjonen skaper sin egen befolkningslov og sin egen overbefolkning relativt til sin egen eksistens. Vi må nøye oss med å vise til at nå det, som Marx viser, først er i det kapitalistiske samfunn at overbefolkningen »fremstår som et resultat av arbeidet selv, « ${ }^{113}$ så innebærer dette at det historisk skapte element selv overtar som den primære determinant $\mathrm{i}$ historien, fremfor den umiddelbare naturdominans som er inneboende $\mathrm{i}$ den umiddelbare befolkningsveksten, en naturdominans som tilsvarer forholdene $\mathrm{i}$ de samfunn som beherskes av grunneiendommen.

Det er først i kraft av denne skildringen i bd. I, 23, »Den kapitalistiske akkumulasjons allmenne lov« at det er riktig å si at kapitalen er totalitet. For kapitalen kan ikke beherske rester av tidligere samfunnsformer uten å beherske, ha inkorporert i seg, disse formers dynamiske prinsipp. Ved sin makt til å konstruere den industrielle reservearmé opphever den dermed alle andre samfunnsforandrende faktorer enn sine egne, og blir dermed en logisk totalitet gjennom sin historiske utvikling: rettere sagt til en totalitet hvor hvert enkelt element også kan fremstilles logisk, dvs. underordnet og vesentlig preget av den overgripende kapital. Den forandrer bare seg selv.

110. Grundrisse, s. 450.

111. Grundrisse, s. 498.

112. »Die ausgesandten Kolonien der Alten z. B. waren Überpopulation.«Ibid.

113. Ibid. 
Også derfor er overgangen gjennom Wakefields koloniseringsteori metodisk akseptabel: de forhold som på den ene siden må vente på grunnrentekategorien for å så sin endelige stadfestelse, får på den andre siden sin plass i fremstillingen rettferdiggjort ved at kapitalens totalitet foregripes ved skildringen av akkumulasjonsloven. Men at denne loven er allmenn og dermed nødvendig, det kan vi ikke under noen omstendighet vite før analysen av den totale, sosiale sammenheng i bd. II. Dette gjelder på tross av at vi må tilbake til bd. I for å finne de metoder kapitalisten konkret benytter seg av for å overbevise oss om at hans drift ikke lar seg forene med noe gitt arbeiderantall.

Men det vi der ser, er ikke til å viske ut. 